Research Article

\title{
Assessment of Biological Spectrum and Phenological Behaviours of Coastal Vegetation in East Midnapore District, Eastern India
}

\author{
Uday Kumar Sen, Ram Kumar Bhakat \\ Ecology and Taxonomy Laboratory, Department of Botany and Forestry, Vidyasagar University, Midnapore \\ 721102, India
}

Article history:

Submission July 2019

Revised December 2019

Accepted January 2020

*Corresponding author:

E-mail: uudaysen@gmail.com

\begin{abstract}
The open coastlines of the world are dominated by sand dunes and salt marshes. They are the primary areas for human recreation and provide a wide range of frequently overlooked ecosystem services. Their intrinsic ecological significance lies in having unique biological assemblies and supporting a range of ecological processes, such as water filtration and nutrient cycling. In addition, in the coastal zone, these areas link marine and terrestrial systems. The objective of this paper is to check the psammophytic species diversity, conservation status and threat; and also prepare a biological spectrum $\mathrm{m}$ in the Costal East Midnapore (CEM) district's sand dune and salt marsh areas. A part of floristic inventories in the CEM, various field trips in different season were carried out, quadrate method is done to examine the ecological impact and richness. Specimens were collected, prepared voucher specimen and enlisted according APG IV classification system to prepare biological spectrum. CEM vegetation was diverse and composed of 162 species of 132 genera distributed among 52 families of 28 orders according to APG IV classification, of which 37 species were exotics. Fabales (19.14\%) and Fabaceae (19.14\%) were the dominant order and family. Biological spectrum shows the study area was classified as "thero-chamaephytic" type of phytoclimate. Mesophyll (24.07\%) and lanceolate as well as oblong (19.14\%) were found to be high in the leaf size spectrum and lamina. The area of study was highly ecotonal potential and fairly undisturbed. This study is useful in comparing and contrasting the adjacent natural vegetation along the gradients of the environment; and recommends effective long-term conservation and better management of the coastal area.
\end{abstract}

Keywords: Biological spectrum, Conservation, Leaf spectra, Life form, Salt marsh, Sand dune

\section{Introduction}

Coastal sand dunes and salt marsh areas are worldwide unique systems. There are wide variations between continents, but many of the selective forces along the coastline are similar [1]. Coastal dunes and salt marshes are characterized by high ecological diversity resulting from a wide range of geomorphologic features, heterogeneity of the environment and variability of species [2].

Coastal dunes provide a collection of habitats that can vary in time and space, where terrestrial habitats can experience critical periods of soil instability, high surface temperatures and salt spray, drought and plant life [3]. Plant life in dunes is often confined to the coastal or adjacent dune fields, facing unstable and harsh environments but not outside the dune area [4].

Salt marshes are generally defined as terrestrial halophytic ecosystems that are natural or semi-natural. They occur largely in the intertidal zone between land and sea and are covered with salt or brackish water for some time at least [5]. The dominant flora, like shrubs and herbs, is made up of halophytic plants. The flora is rather poor in species [6].

\section{How to cite:}

Sen UK, Bhakat RK (2020) Assessment of Biological Spectrum and Phenological Behaviours of Coastal Vegetation in East Midnapore District, Eastern India. Journal of Tropical Life Science 10 (2): 123 - 140. doi: 10.11594/jtls.10.02.05. 


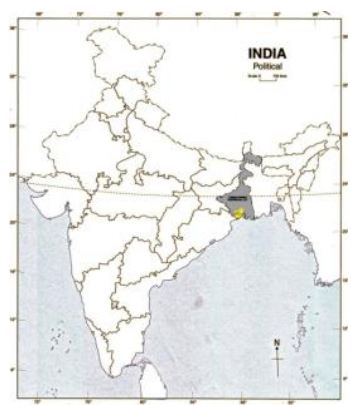

(a)

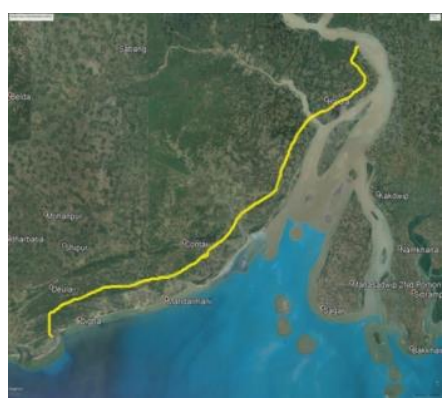

(b)

Figure 1. Map showing East Midnapore district in West Bengal under India (a) and study site (from line to coast) (b)

The sediment is made up of sand and mud. The salt marshes are usually associated with flats of mud, but they also occur on flats of sand. Sediment supply and salt marsh plants' ability to withstand tidal flooding are key factors in determining whether or not salt marshes develop [7]. Salt marshes are established where sediment builds up to a point where it is possible to establish pioneer plants. This early salt marsh vegetation consists of a small number of salt-tolerant (halophytic) species and is most frequently found on intertidal surfaces, where the roots of germinating plants remain undisturbed for several days by tidal action [8]. It is also important as the level of shelter from wave action. Fine sediments (>20\%) in the surface layers of the flats enhance shear strength and settling and survival [9].

All species of dunes and salt marsh show a degree of fitness to local environments but do not share a common set of characteristics. In this regard, such containment of plants also produces a biogeographic substitution with a floristic change of vegetation along the coasts in a sequenced substitution of taxa: species, subspecies and varieties give way to each other along the coastal stretch [10].

The adaptation of a plant to certain ecological conditions determines a life form; therefore, it is an important physiognomic characteristic that has been widely used in the analysis of vegetation. It indicates a certain area's macro and microclimate and human disturbances [11]. Raunkiaer [12] proposed the term "biological spectrum" to express the distribution of life-form in a flora as well as the phytoclimate under which the prevailing lifeforms evolved. Plant species may be grouped into five main classes under this system, i.e. phanerophytes, chamaephytes, hemicryptophytes, crypto- phytes and therophytes.

The percentage of various life form classes put together is called as the biological spectrum. Raunkiaer [12] had built a normal spectrum that may act as a model against which spectra may be compared in different life forms. The normal spectrum of Raunkiaer indicates a phanerophytic community and the deviation (from it) determines a habitat's phytoclimate. The occurrence in different regions of similar biological spectra indicates similar climatic conditions. Thus, the differences between normal spectrum and life forms of the biological spectrum may point to which life form characterizes the phytoclimate or vegetation. The main objective of this study was therefore to investigate the floristic composition and biological spectrum of the coastal sand dune and salt marsh areas of East Midnapore District in order to determine the prevailing plant families that reflect together the region's phytoclimatic and coastal arid conditions.

\section{Material and Methods \\ Description of the study area}

East Midnapore district (22 $57^{\prime} 10^{\prime \prime}$ $21^{\circ} 36^{\prime} 35^{\prime \prime} \mathrm{N}$ and $88^{\circ} 12^{\prime} 40^{\prime \prime}-86^{\circ} 33^{\prime} 50^{\prime \prime} \mathrm{E}$, average altitude 7 masl) is one of West Bengal's 18 administrative districts having its headquarter in Tamluk. On January 1, 2002, the district was carved from the former district of Medinipur. It is bordered in the south by the Bay of Bengal, in the east by the Rupnarayana River and in the west by Subarnarekha. The Bay of Bengal and these great rivers and their numerous branches have created a flourishing and easy water navigation system that fosters trade, culture and early contact with people outside the region. These rivers, at the same time, 
UK Sen, RK Bhakat, 2020 / Biological Spectrum and Phenological Behaviours of Coastal Vegetation

Table 1. Total angiosperm taxa

\begin{tabular}{cccccccccc}
\hline Angiosperm & \multirow{2}{*}{\begin{tabular}{c}
\multirow{2}{*}{ type } \\
Orders
\end{tabular}} & \multirow{2}{*}{ Families } & \multirow{2}{*}{ Genera } & \multicolumn{5}{c}{ Species } \\
\cline { 5 - 9 } & & & & Herbs & Shrubs & Trees & Climber & Total \\
\hline Dicots & 22 & 44 & 109 & 41 & 29 & 46 & 19 & 135 \\
Monocots & 6 & 8 & 23 & 18 & 4 & 3 & 2 & 27 \\
Total & 28 & 52 & 132 & 59 & 33 & 49 & 21 & 162 \\
\hline
\end{tabular}

help develop the vegetation of plants in this region. West Midnapore, Howrah and South 24 Pargana in West Bengal and Balasore in Odisha are the surrounding districts (Figure 1a).

According to the 2011 census, the district is spread over an area of $4295 \mathrm{~km}^{2}$ with a population of 5,094,238 people (population density; $1076 / \mathrm{km}^{2}$ ). Approximately $90 \%$ of the population lives in the rural areas of this district [13]. The survey was conducted on sand dune and salt marsh areas on the coastal stretch of East Midnapore district, assuming the type of vegetation will vary with the altitude variation that may affect the phytoclimate internally (Figure 1b).

\section{Field survey and data collection}

During the period from December 2013 to January 2019, the CEM was thoroughly surveyed 142 plots $\left(1 \mathrm{~km}^{2}\right.$ each) by stratified random sampling method in different seasons to study ecological perspectives. Floristic surveys were conducted on the basis of "spot identification". Samples of plants with flowers or fruits were collected for unknown plants. The specimens were processed, preserved, poisoned and mounted on herbarium sheets to prepare voucher sheet of specimens using standard and modern herbarium techniques after collection [14]. Photographs were taken of some common, locally rare, endemic and valuable plant species. Herbarium sheets were identified by matching properly annotated materials available at Vidyasagar University's Herbarium. Several relevant catalogs [15], regional floras [16-20], monographs [21], revision works [22] and other literature were consulted for identification purposes.

\section{Analysis of vegetation}

In the systematic enumeration of the taxa; clades, order, family, species along with voucher number, habit, life-span, nativity, flowering and fruiting time, life-form of Raunkiaer with subtype, leaf spectra, shape of the leaf lamina, red list status of IUCN [23] and distribution of plants in the coast in summer, rainy and winter seasons were arranged according to the classification of Angiosperm Phylogeny Group IV [24] (Supplementary 1). An additional summary table to show the total number of orders, families, genera and species in dicots and monocots was prepared (Table 1). All the species were classified into different categories of Raunkiaer's life form depending on the position of regenerating parts or propagules in all the species collected and a biological spectrum was prepared for the area, which was subsequently compared to the normal spectrum of the Raunkiaer to determine the phytoclimate of the coastal area [12, 25, 26] (Supplementary 1 and Table 2). Knowledge about leaf size and lamina became very helpful to understand plant physiological development and plant communities played useful role in classifying plant associations. Various plant leaf sizes were arranged with the life forms of their respective Raunkiaer [12] (Table 2). Plants were divided into (a) leptophyll $\left(<25 \mathrm{~mm}^{2}\right)$, (b) nanophyll (25-225 $\mathrm{mm}^{2}$ ), (c) microphyll (225$2025 \mathrm{~mm}^{2}$ ), (d) notophyll (2025-4500 $\left.\mathrm{mm}^{2}\right),(\mathrm{e})$ mesophyll (4500-18225 $\mathrm{mm}^{2}$ ), (f) microphyll $\left(18,225-164,025 \mathrm{~mm}^{2}\right)$ and (g) megaphyll (> $\left.164,025 \mathrm{~mm}^{2}\right)$ [12].

\section{Results and Discussions Different plant taxa}

In this study, according to the APG IV (2016) classification, a total of 162 species belonging to 132 genera distributed among 52 families of 28 orders were recorded from the study area (Table 1 ). Rosids and Asterids were the top two clades. Approximately $82 \%$ of the flora was represented by orders from Eudicot and Core Eudicot. The major contributions ( $\geq 10$ species) were from Fabales 31 (19.14\%), Caryophyllales 16 (9.88\%), Poales 16 (9.88\%), Lamiales 14 (8.64\%), Malpighiales 13 (8.02\%), Gentianales 11 (6.79\%), and Malvales 10 (6.17\%) (Figure 2).

The ten dominant plant families encompassed 


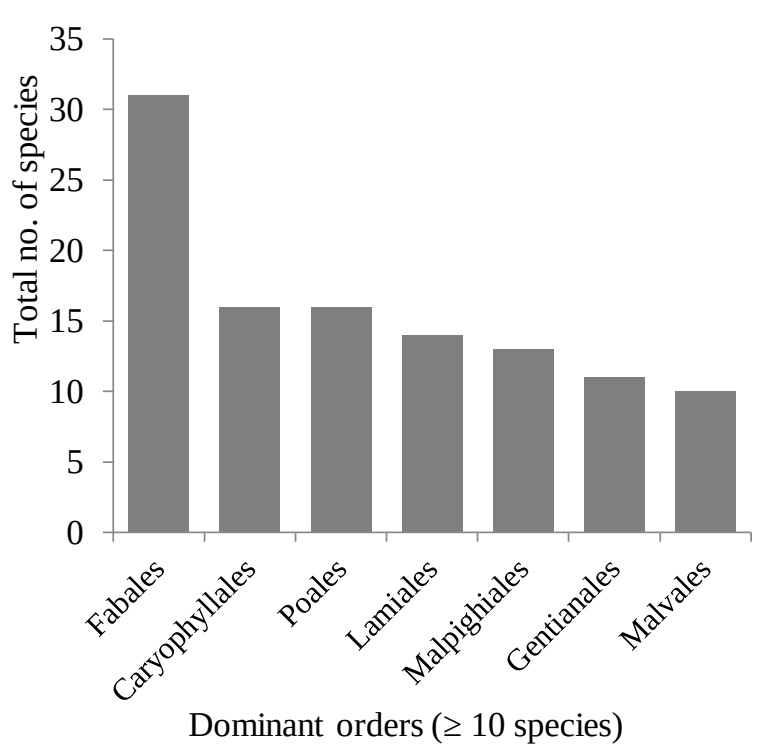

Figure 2. Major contribution of orders ( $\geq 10$ species) in the study site

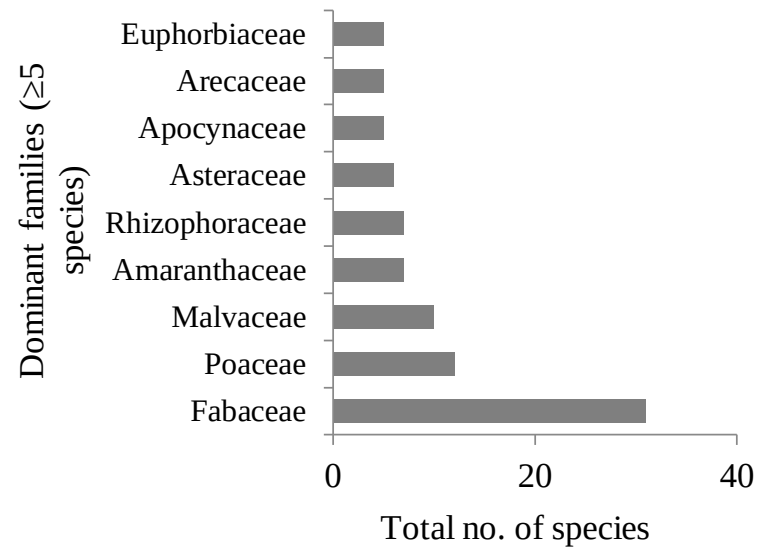

Figure 3. Major contribution of families ( $\geq 5$ species) in the study site

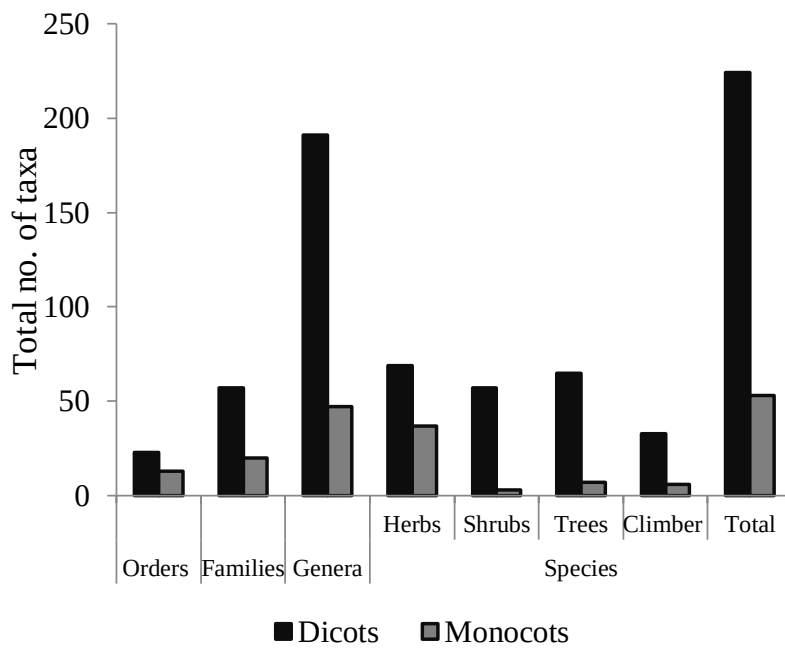

Figure 4. Total angiosperm taxa more than $56 \%$ genera with descending numbers ( $\geq 6$ species) were Fabaceae 22 (16.67\%), Poaceae 11 (8.33\%), Malvaceae 7 (5.30\%), Amaranthaceae 6 (4.55\%), Asteraceae 6 (4.55\%), Apocynaceae 5 (3.79\%), Euphorbiaceae 5 (3.79\%), Arecaceae 4 (3.03\%), Rhizophoraceae 4 (3.03\%) and Rubiaceae 4 (3.03\%) (Figure 3).

The six well represented genera were Crotalaria (4 species), Ceriops (3 species), Heritiera (3 species), Opuntia (3 species), Sonneratia (3 species) and Tephrosia (3 species). Acacia, Acanthus, Avicennia, Bruguiera, Cyperus, Derris, Eragrostis, Leucas, Pandanus, Phoenix, Prosopis, Rhizophora, Salvadora, Senna, Sida, Suaeda, Tamarix and Ziziphus were the 18 well represented genera with 2 species. There was only one species in another 107 genus (Supplementary 1). In all, 125 species $(77.16 \%)$ were native, while 37 (22.84\%) species were exotic (Supplementary 1).

\section{Species diversity in different growth form}

The current floristic study of CEM showed that it harboured a total of 162 plant species [dicots 135 (83.34\%) and monocots 27 (16.66\%)] of the genera 132[dicots 109 (82.58\%) and monocots 23(17.42\%)] of 52 families [dicots 44 (84.62\%) and monocots $8(15.38 \%)$ ] under 28 orders [dicots 22 (78.57\%) and monocots 6 (21.43\%)]. Of the reported species, 59 (36.42\%) were herbs.

Other species reported were 33 shrubs (20.37\%), 49 trees (30.25\%) and 21 climbers (12.96\%) (Table 2). Amongst the total dicots 135 (83.34\%) and monocots 27(16.66\%), herbs, shrubs, trees and climbers represented $41,29,46$, 19 and 18, 4, 3, 2 species respectively, representing $25.31 \%, 17.90 \%, 28.40 \%, 11.73 \%$ and $11.12 \%, 2.46 \%, 1.85 \%, 1.23 \%$ of the total species (Figure 4).

Major four herbaceous families ( $\geq 5$ species) were Poaceae 12 (20.34\%), Fabaceae 8 (13.56\%), Amaranthaceae $6(10.17 \%)$ and Asteraceae 5 (8.47\%) held above $52 \%$ of the total herb population. The three major less-woody shrub families were Fabaceae 8 (24.24\%), Malvaceae 4 (12.12\%) and Cactaceae $3(9.09 \%)$ held above $45 \%$ of the total shrub population. Fabaceae 8 (16.33\%), Rhizophoraceae 7 (14.29\%), Malvaceae 5 (10.20\%) and Arecaceae 3 (6.12\%) were four highly diversified families with over $46 \%$ of the total tree pop- 
Table 2. Biological spectrum (\% of all life forms) of study site and its comparison with Raunkiaer's normal spectrum.

\begin{tabular}{ccccc}
\hline Life forms & $\begin{array}{c}\text { Total no. } \\
\text { of species }\end{array}$ & $\begin{array}{c}\text { Biological spec- } \\
\text { trum (\%) of the } \\
\text { study site }\end{array}$ & $\begin{array}{c}\text { Raunkiaer's nor- } \\
\text { mal spectrum (\%) }\end{array}$ & $\begin{array}{c}\text { Deviation= (Raunkiaer's } \\
\text { normal spectrum- Bio- } \\
\text { logical spectrum) }\end{array}$ \\
\hline Phanerophytes (Ph) & 76 & 46.91 & 46.00 & 0.91 \\
Megaphanerophytes $(M M)$ & 8 & 4.94 & 3.00 & 1.94 \\
Mesophanerophyte $(M)$ & 17 & 10.49 & 28.00 & -17.51 \\
Nanophanerophytes $(\mathrm{N})$ & 51 & 31.48 & 15.00 & 16.48 \\
Chamaephytes (Ch) & 22 & 13.58 & 9.00 & -17.98 \\
Hemicryptophytes (He) & 13 & 8.02 & 26.00 & -4.77 \\
Cryptophytes (Cr) & 2 & 1.23 & 6.00 & 17.25 \\
Therophytes (Th) & 49 & 30.25 & 13.00 &
\end{tabular}

ulation. Another five families included 2 species and sixteen families of single tree species. The three most speciose families in descending manner included Fabaceae 7 (33.33\%), Apocynaceae 3 (14.29\%) and Convolvulaceae 2 (9.52\%) clasp above $57 \%$ of the total liana population (Supplementary 1).

\section{Life span}

In the CEM, in one growing season, 44 (27.16\%) annual plants would go through their life cycle. Whereas, 118 (72.84\%) perennial plants that could survive the most unfavourable conditions and could stay alive for more than two years (Supplementary 1).

\section{Raunkiaer's life form and its distribution}

Phanerophyte, one of the life-form categories of Raunkiaer, was a plant whose perennial buds or shoots apices bore on aerial shoots and the four most speciose families ( $\geq 5$ species) in descending form included Fabaceae 17 (22.37\%), Rhizophoraceae 7 (9.21\%), Arecaceae 5 (6.58\%) and Malvaceae 5 (6.58\%) containing more than 44\% of the total phanerophytes. Four majors descending chamaephytic families ( $\geq 2$ species) were Fabaceae 6 (27.27\%), Cactaceae 3 (13.64\%), Malvaceae 2 (9.09\%) and Rutaceae 2 (9.09\%) with a total population of $59.09 \%$. Two leading hemicryptophytic families explicitly contained Poaceae 7 (53.85\%), Cyperaceae 4 (30.77\%) and 84.62\% of the total population. Aponogetonaceae 1 (50\%) and Ruppiaceae 1 (50\%) were only two cryptophytic families. The four main therophytic families ( $\geq 5$ species) were Fabaceae 8 (16.33\%), Amaranthaceae 6 (12.24\%), Asteraceae 5 (10.20\%), Poaceae 5 (10.20\%) and the total population of
48.98\% (Supplementary 1).

\section{Life form and biological spectrum}

The biological spectrum showed that phanerophytes 76 (46.91\%) were the dominant followed by therophytes 49 (30.25\%), chamaephytes 22 (13.58\%), hemicryptophytes 13 (8.02\%), and cryptophytes 2 (1.23\%). The phanerophytes,nanophanerophytes 51 (31.48\%) were the dominant than mesophanerophytes 17 (10.49\%) and megaphanerophytes 8 (4.94\%) (Supplementary 1 and Table 2).

This study revealed that therophytes, chamaephytes and phanerophytes constituted the higher percentage $17.25 \%, 4.58 \%$ and $0.91 \%$ respectively than the normal spectrum exhibiting "therochamaephytic" phytoclimate (phanerophytes was negligible, because its value $<1 \%$ ). Further, the number of hemicryptophytes (17.98\%) and cryptophytes $(4.77 \%)$ were comparatively smaller in percentage than the Raunkiaer's normal spectrum (Table 2). Out of the total phanerophytes, nanophanerophytes (16.48\%) and megaphanerophytes (1.94\%) were somewhat larger and mesophanerophyte (17.51\%) was a comparatively smaller value than the Raunkiaer's normal spectrum (Figure 5).

\section{Leaf size spectra}

The overall spectrum of leaf sizes showed that leptophyll 12 (7.41\%), nanophyll 38 (23.46\%), microphyll 30 (18.52\%), notophyll 23 (14.20\%), mesophyll 39 (24.07\%), macrophyll 10 (6.17\%) and megaphyll 10 (6.17\%) existed. Cyperaceae 3 (1.85\%), Fabaceae 16 (9.88\%), Fabaceae 5 (3.09\%), Fabaceae 4 (2.47\%), Rhizophoraceae 7 (4.32\%), Malvaceae 2 (1.23\%) and Arecaceae 5 
Table 3. Life-form analysis with different leaf size

\begin{tabular}{|c|c|c|c|c|c|c|c|c|}
\hline \multirow{2}{*}{$\begin{array}{l}\text { Raun- } \\
\text { kiaer's } \\
\text { life form }\end{array}$} & \multicolumn{7}{|c|}{ Leaf spectra } & \multirow{2}{*}{ Total } \\
\hline & Le & $\mathrm{Na}$ & Mi & No & $\mathrm{Me}$ & Ma & $\mathrm{Mg}$ & \\
\hline $\mathrm{Ph}$ & 2 & 11 & 9 & 10 & 29 & 7 & 8 & 76 \\
\hline$M M$ & 1 & 0 & 1 & 1 & 1 & 2 & 2 & 8 \\
\hline$M$ & 0 & 4 & 1 & 1 & 8 & 2 & 1 & 17 \\
\hline$N$ & 1 & 7 & 7 & 8 & 20 & 3 & 5 & 51 \\
\hline $\mathrm{Ch}$ & 3 & 2 & 7 & 4 & 4 & 1 & 1 & 22 \\
\hline $\mathrm{He}$ & 5 & 3 & 2 & 0 & 3 & 0 & 0 & 13 \\
\hline $\mathrm{Cr}$ & 0 & 1 & 0 & 0 & 0 & 1 & 0 & 2 \\
\hline Th & 2 & 21 & 12 & 9 & 3 & 1 & 1 & 49 \\
\hline Total & 12 & 38 & 30 & 23 & 39 & 10 & 10 & 162 \\
\hline
\end{tabular}

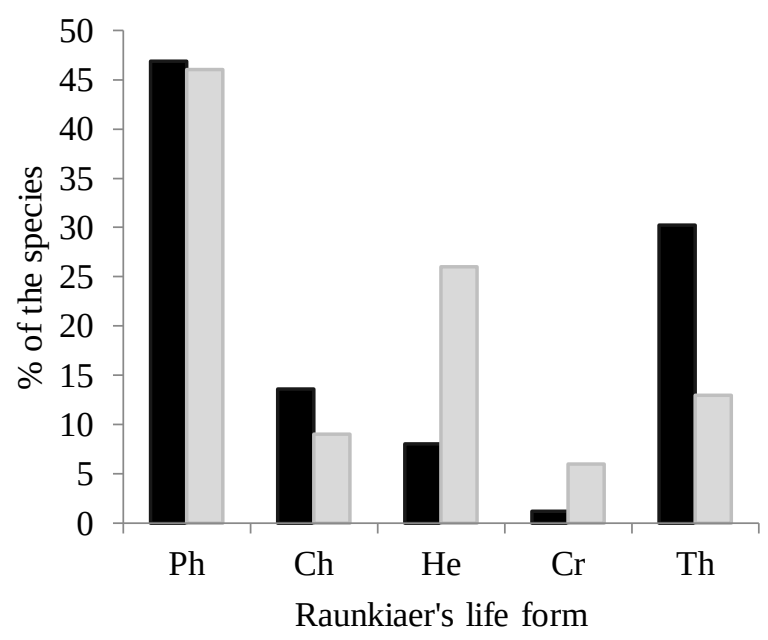

Biological spectrum (\%) of the study site $\square$ Raunkiaer's normal spectrum (\%)

Figure 5. Comparison of Biological spectrum with Raunkiaer's normal spectra

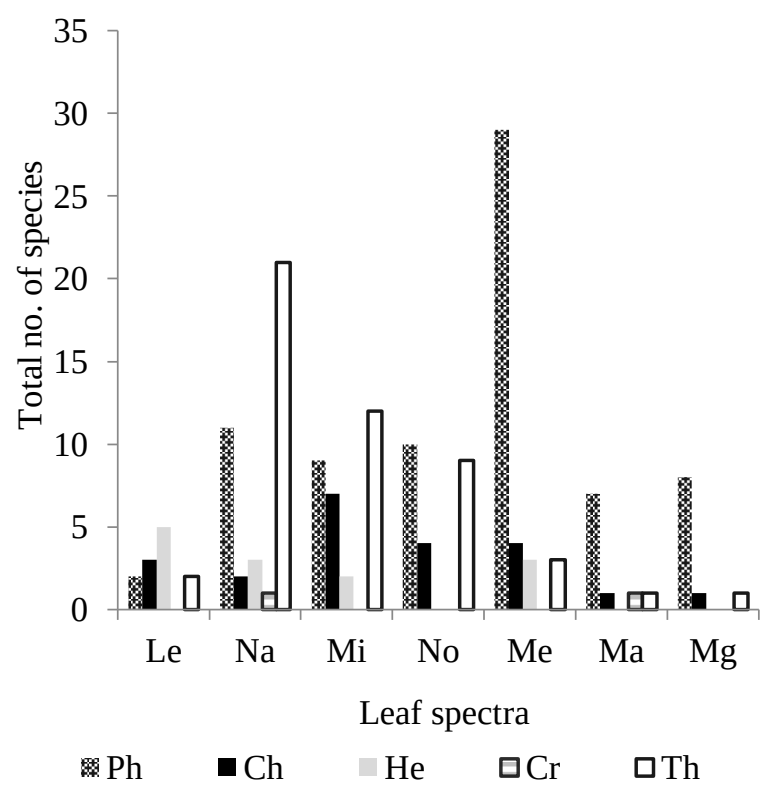

Figure 6. Analysis of life form with different leaf size
(3.09\%) were dominant leptophyll, nanophyll, microphyll, notophyll, mesophyll, macrophyll and megaphyll families (Table 3).

As regards the spectrum of the leaf size, mesophyll had been found to be the high followed by nanophyll, microphyll, notophyll, leptophyll, macrophyll and megaphyll (Figure 6). In case of leaf spectra, the presence of leptophyll 5 (3.09\%), nanophyll 21 (12.96\%), microphyll 12 (7.41\%), notophyll 10 (6.17\%), mesophyll 29 (17.90\%), macrophyll 7 (4.32\%) and megaphyll 8 (4.94\%) have the maximum in comparison to hemicryptophytes, therophytes, therophytes, phanerophytes, phanerophytes, phanerophytes and phanerophytes respectively (Table 3 ).

\section{Shape of the leaf lamina and phenology}

Leaf was generally a flat, green photosynthetic organ on the stem. As regards the shape of leaf lamina (Supplementary 1), lanceolate 31(19.14\%) and oblong 31 (19.14\%) were found to be the maximum followed by linear 26 (16.05\%), cordate 21 (12.96\%), ovate 21 (12.96\%), obovate 13 (8.02\%), acicular 7 (4.32\%), palm like 5 (3.09\%), spathulate $3(1.85 \%)$, orbicular $1(0.62 \%)$, reniform 1 $(0.62 \%)$, sagitate $1(0.62 \%)$ and subulate 1 $(0.62 \%)$ (Figure 7 ).

The vegetation phenology observed during different seasons revealed that most of the species were dominant in rainy seasons 161 (99.38\%), followed by winter 131 (80.86\%) and summer 103 (63.58\%) (Supplementary 1). Seasonally habitwise species content varied; in the summer season, tree $>$ shrub climber $>$ herb; rainy season, herb $>$ tree $>$ shrub $>$ climber; winter season, tree $>$ herb $>$ shrub $>$ climber, respectively (Figure 8).

\section{IUCN categories}

92 plants have not yet been evaluated till now. There might be 63 species of Least Concerned (LC), 3 Near Threatened (NT), 1 Data Deficient (DD), 1 Critically Endangered (CR), 1 Endangered (EN) and 1 Vulnerable (VU) species according to the IUCN (Supplementary 1) [23].

\section{Discussion: Patterns of the floristic diversity}

In this study, the presence of 162 plant species belonging to 132 genera, 52 families and 28 orders indicates a significant level of plant diversity. These species formed various communities tailored to their ecological needs and the manage- 


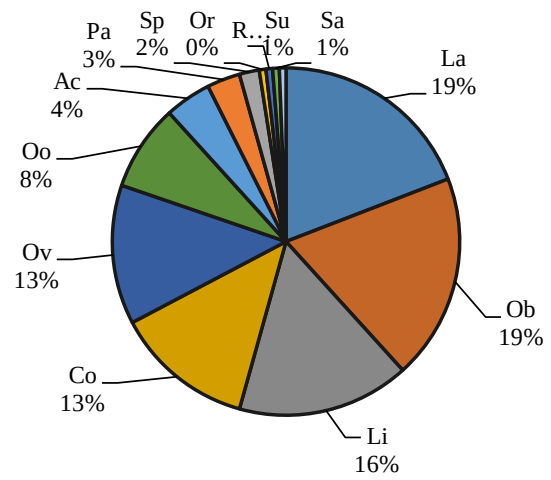

Figure 7. Different types of leaf lamina (Li: linear, Co: cordate, Ov: ovate, Oo: obovate, Ac: acicular, Pa: palm like, Sp: spathulate, Or: orbicular, Re: reniform, Sa: sagitate, and Su: subulate)

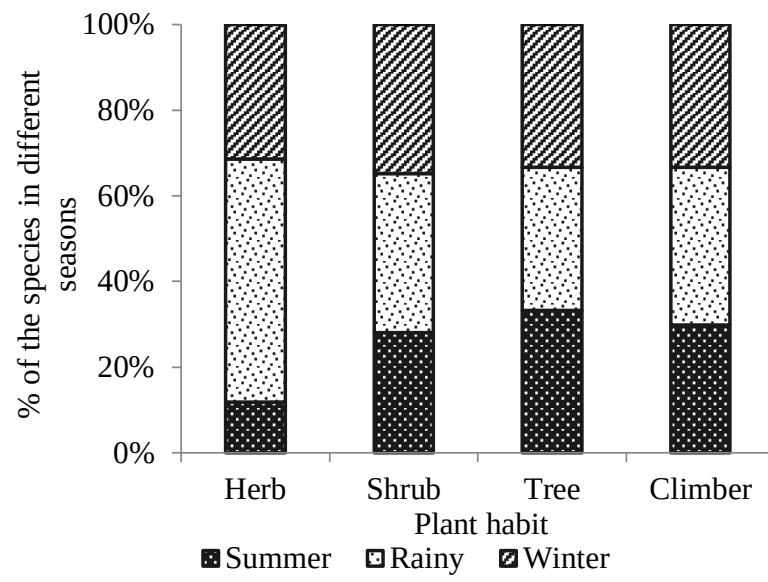

Figure 8. Vegetation phenology of the study site

ment that human beings had imposed over the past few years. It appears that the topographic, edaphic and physiographic conditions caused high plant diversity in the area. Of course, the micro-climatic factor was also effective in this respect, but there were fewer variations in the area's climate conditions than the other factors [27]. From the study, Rosids and Asterids could be identified as the dominant clades; Fabales, Caryophyllales, Poales, Lamiales, Malpighiales, Gentianales and Malvales were the dominant orders. Wing, Magallon and Castillo and Wang et al. [28-30] highlighted similar dominance and distribution in angiospermdominated areas. Fabaceae, Poaceae, Malvaceae, Amaranthaceae, Rhizophoraceae, Asteraceae, Apocynaceae, Arecaceae and Euphorbiaceae were the well-represented families. The result was consistent support from the study as the families emerged as the common taxa in the area under investigation because their wide ecological ampli- tude showed diversity in the occurrence of their habitat [31, 32].

Of the total recorded 162 species, 125 species were native, while 37 species were alien, most of which thrive in the coastal disturbed habitats. Because alien plant species tended to be more plasticity than native plants and in several fitness components superior to natives, they were usually able to colonize in disturbed areas more efficiently than native species, regardless of their life history strategy [33]. Common exotic invasive species growing in the coastal areas were therefore herbs (Aerva javanica, Ageratum conyzoides, Alternanthera sessilis, Argemone mexicana, Parthenium hysterophorus, Pluchea lanceolata), shrubs (Chromolaena odorata, Ricinus communis) and trees (Eucalyptus globulus, Prosopis juliflora). The unsustainable anthropogenic activities in these areas had been considered as a major threat to the native flora in recent times [34]. The introduction of alien species posed a serious threat to the endemic flora because of its increased competitiveness [35]. Once naturalized in their non-native ranges, these alien plant species had the potential to compete with a region's native flora, paving the way for the biological invasion phenomenon. This process of invasion could change the floristic composition and modify the functioning of the region's ecosystem [33].

Traditionally, East Midnapore district's coastal dune ecosystem was considered poor in nutrients, both due to repeatedly disturbing soil conditions characterized by well-sorted aeolian sand and relatively low air nutrient input as opposed to inland ecosystems. The very low carbon content in the soil horizons was a major feature of coastal heath as opposed to inland heath [36]. The main vegetation characteristic of the coastal dunes was the open structure, which was caused by sand drift together with processes of dune stabilisation and the episodic transgressive dune formation, which constantly reset the succession process [37]. Other alien exotic species as recorded from the region during the current study were likely to become serious plant invaders in the immediate future and therefore need immediate attention and appropriate management action.

\section{Discussion: Patterns in Biological spectrum}

Therophytes and chamaephytes were general- 
ly well represented in the biological spectra of the study area, then the normal spectrum exhibiting "thero-chamaephytic" phytoclimate. Therophytes showed the maximum divergence of the normal spectrum; the similar phytoclimatic association had also been reported by other workers for different tracks of vegetation [38]. Therophytes were expected to become dominant where growing conditions were so adverse that the probability of survival until the second year became very poor [39, 40]. However, unfavourable growing conditions for part of the year did not hinder the occurrence of perennials, as they favoured selection by other strategies, such as dormant structures that enabled species to survive in harsh conditions. Therophytes usually dominated in some of the driest environments of the world [41]. The highest percentage of therophytes taking place in the area was the trait of the subtropics and often related to soil and climatic conditions [42]. The prevalence of therophytes was accredited to diverse factors like widespread microclimate of the region united with degradation and destruction of dune ecology, human interferences, stone fencing, species to resist drought, salinity and sand accumulation etc. Such pattern was also reported by other workers [4344]. Thus, the present study reveals that the vegetation was predominantly sub-tropical type having a higher percentage of therophytes and chamaephytes as compared to normal biological spectra. Prevalence of therophytes was also an indicator of biotic pressure [45]. The growth of therophytes was much favoured in disturbed areas [46]. According to Meher-Homji [47], the life forms were reflected by bioclimate of the area.

Generally, in all the seasons and in rainy season in particular, therophytes and nanophanerophytes remained dominant due to favourable growing season. During the start of rainy season, there was always flush of annual plants. The dominance of therophytes occurred due to unfavourable habitat conditions [48].

Hemicryptophytes were mainly represented by grasses, because the upper layer of the sand dune contains more organic matter, it had a higher capacity for holding water during the dry season, while it had a higher level of oxygen than the lower ones during the rainy season. It might explain the fact that hemicryptophytes were more dominant in the slopping area with poor drainage [49]. In addition, there were others anatomical ad- justments that favored monocots in partly marshy areas [50].

Lavrentiades [51] also considered therophytes and chamaephytes as the major life forms in unfavourable conditions in the coastal dune and open physiognomies. In the investigated area hot and dry and waterlogged condition coupled with overgrazing led to harsh conditions. The results also agree with Mack [52], who also stated that the characteristics of subtropical habitats were therophytes and nanophanerophyes. However, in the Indian tropics, cryptophytes died back to underground storage organs to survive the unfavourable dry period, fire, etc. In the tropical ecosystem, cryptophytes were conceived as relics of the paleoclimate, which prevailed prior to the present exterminating of the Indian subcontinent [53-54]. According to Zohary [55], a fraction of the flora of a place might be in discordance with the present-day climate and could be the remnant of past climate. In this regard, the coastal areas of East Midnapore district are floristically rich and potential for further research in future.

Therophytes were adapted in vacant niches indicates that the investigated area was under heavy biotic pressure [56]. Many plant species were decreasing in the area. It would be the moral and ethical duty of the local people to protect the plant resources. Most of the plants were uprooted for burning purposes and grazed by the livestock. It, therefore, seemed appropriate to manage the grazing system. The sand dune and salt marsh area were refuge for valuable and endangered plants. Further study is needed to quantify the data and suggest plans for the conservation of the area.

\section{Discussion: Patterns in leaf size spectra, leaf lamina and phenology}

Although the leaf spectra were distributed in seven different types, it was mostly dominated by ( $\geq 14 \%$ ) mesophyll, nanophyll, microphyll and notophyll (80.25\%); while the remaining three leaf size types were least represented (19.75\%) in the total species pool. Leaf spectra tell us about the community's plant adaptation and association. Small leaves were present at the base whereas the large leaves were present at high altitude and correlated with climate warming and the availability of water in the soil [57]. The medium type of leaf size showed the subtropical type of climate [58]. In the study site, the elements of meso and nano- 
phyllous were dominant, showing moisture and perennial availability of water or wet condition [59].

In the present study it was observed that due to the presence of therophytes and chamaephytes, the proportion of different leaf size classes changed seasonally. However, in all seasons, the phanerophytes and some chamaephytes nearly retained the same status. Other plant characteristics like habit and root system could also play a major role [60]. For the ecological study of the region, the leaf spectra and biological spectrum alone were not sufficient, but quantitative studies such as vegetation structure and conservation were consequential equipment [61, 60].

The type of leaf lamina exists in a variety of forms, ranging from lanceolate to subulate. The shape of the leaf helps plants optimize light capture and water loss and minimizes the avoidable energy consumption in leaf production [62]. The distribution of leaf sizes in different resource poor environments strongly supports this theory [63]. Not only do leaf laminas vary in size, but some leaves have distinct serrations, and the blades are almost completely dissected even in some leaves. Leaf dissection helps plants reduce self-shading and in turn plays a role in ensuring that the adjacent leaves get sufficient light [64].

The change in species composition within the community is accompanied by significant seasonal changes [65]. As the climate of the study region had well-defined seasons, the vegetation phenology observed during different seasons revealed a significant difference in vegetation among the seasons. Most species dominated during the rainy season $(99.38 \%)$, followed by winter $(80.86 \%)$ and summer (63.58\%). Expectedly, it may be attributed to the fact that a high proportion of therophytes and chamaephytes in the region appeared during rainy and winter seasons.

\section{Discussion: IUCN categories}

Based on the above-mentioned phytosociological analysis with ecological information on IUCN Red Listed plants, it is revealed that plants are still present and regenerate in the undisturbed sand dune and salt marsh areas but locally disappear in highly disturbed areas. This study would highlight the status and distribution of the species in the study area, the ecological characteristics necessary for their survival, and the threats to some of the species identified by following the IUCN [23] criteria. It is because IUCN Red List applications are a global plant diversity barometer [66].

The increase in the number of vulnerable species in the area was caused by various factors. Environmental pressures were ultimate or proximate [67]. The latter included recreational activities, the construction of related infrastructure, pollution, construction, ecologically harmful beach management, off-road vehicle and resource exploitation. The former included human population size, consumption rates and technology. By contrast, the most effective factors on the Red listed species; i.e. Brownlowia tersa, Ceriops decandra, Phoenix paludosa (near threatened); Porteresia coarctata (data deficient); Sonneratia griffithii (critically endangered); Heritiera fomes (endangered), and Intsia bijuga (vulnerable) were determined to be limited population and low natural reproduction. Human activity, such as plant overexploitation and land use change, was the most important factor that caused the deterioration of these species.

\section{Conclusion}

The present study denotes the possibility of using Raunkiaer's approach to ascertain the remarkable distinctions between the communities of angiosperm psammophyte and salt marsh plants in a coastal landscape or biome and their associations, the proportion of species in floristic life forms that led by existing ecological parameters and environmental gradients. Life forms analysis gives a clear picture of the coastal areas biological spectrum. Therophytes and chamaephytes each share the significance of the "thero-chamaephytic" phytoclimate in the present study. This study may therefore be useful in comparing and contrasting the adjacent natural vegetation along the gradients of the environment, revealing more information about the ecosystem than the mere cover of the mobile and fixed dunes vegetation. It also suggests that by directing succession, the biotic factors play an important role in shaping a landscape's vegetation. This indicates the influence on the sand dunes and salt marshes of anthropogenic disturbance that fa vours the growth of more therophytes.

Although fairly protected sand dunes and salt marshes vegetation face some mild threats due to the influx of a large number of recreational activities, littering the place with plastic bags and ther 
mocouple plate, human trampling on seedlings, loss of climax vegetation, erosion, illegal construction, pollution, ecologically harmful beach management, off-road vehicle and resource exploitation and exotic weed invasion. Therefore, the following aspects should require instant attention for effective long-term conservation and better management of the coastal area:

1. East Midnapore district's sea beaches, embryo and fore dunes are eroding due to human-induced changes in the supply and transportation of sediments, sea-level rise, and increased storminess. In general, eroding beaches migrate inland. Enabling natural retreat is an ecologically ideal management response.

2. Human activities have a more subtle and direct impact on the beach, embryo and fore dunes in addition to erosion. Increasing demand as places for recreational activities on beaches and dunes may have detrimental effects on heavy-use intensities such as vehicles driven off-road beach.

3. However, the society is not able to respond adequately to these pressures, as many of the beaches' and dunes' fundamental ecological properties remain poorly understood.

Worldwide beaches and dunes contain unappreciated biodiversity and provide a range of services and values that are not covered by any other ecosystem. These environments face increasing threats, especially as a consequence of "coastal squeeze." It should be a priority to talk about beaches that are biologically diverse, functioning ecosystems and support sustainable low impact human uses. Scientists, managers, policy makers and the public will have to work together to formulate and implement appropriate coastal zone management policies for this purpose. If we continue to take beaches as granted and neglect their ecology, this will not be achieved.

\section{Acknowledgment}

The authors are thankful to the local communities for sharing their knowledge of plants and helping during the field survey.

\section{References}

1. Maun MA (2009) The biology of coastal sand dunes. Oxford University Press, United Kingdom.

2. Adam P (1993) Saltmarsh ecology. United Kingdom, Cam- bridge University Press.

3. Novo FG, Barradas MD, Zunzunegui M et al. (2008) Plant functional types in coastal dune habitats. In: Martinez ML, Psuty NP, eds. Coastal dunes: ecology and conservation. Berlin, Heidelberg, Springer, Germany. pp 155-169.

4. Todd CB (1994) A comparison of the reproductive strategies of key species of a prograding dune system in the Mlalazi Nature Reserve. Doctoral dissertation, Rhodes University, Natal.

5. Doody JP (2008) Saltmarsh conservation, management and restoration, (Vol. 12). Springer Science \& Business Media, Germany.

6. Martinez-Lopez J, Teixeira H, Morgado M et al. (2019) Participatory coastal management through elicitation of ecosystem service preferences and modelling driven by "coastal squeeze”. Science of the Total Environment 52: 1113-1128.

7. Quante M, Colijn F, Bakker JP et al. (2016) Introduction to the assessment-characteristics of the region. In: Quante M, Colijn F, eds. North sea region climate change assessment. Springer, Cham. pp 1-52.

8. Wolters M, Garbutt A, Bekker RM et al. (2008) Restoration of salt-marsh vegetation in relation to site suitability, species pool and dispersal traits. Journal of the Palaeontological Society of India 45(3): 904-912.

9. Packham JR, Willis AJ (1997) Ecology of dunes, salt marsh and shingle. Springer Science \& Business Media, Germany.

10. Garcia-Mora MR, Gallego-Fernandez JB, Garcia-Novo F (1999) Plant functional types in coastal foredunes in relation to environmental stress and disturbance. Journal of Vegetation Science 10(1): 27-34.

11. Cain SA, Castro GDO (1959) Manual of vegetation analysis. Harper and Brothers, New York, USA.

12. Raunkiaer C (1934) The life forms of plants and statistical plant geography. Clarendon Press, England.

13. Anon (2011) District census of East Midnapore, https://www.census2011.co.in (Accessed 20 May 2019).

14. Jain SK, Rao RR (1977) A handbook of field and herbarium methods. Today and Tomorrow's Printers and Publishers, New Delhi, India.

15. Anderson T (1862) Catalogue of plants indigenous in the neighbourhood of Calcutta with directions for examination and preservation of plants, Calcutta, India.

16. Hooker JD (1872-1897) The flora of British India, Vol. I-VII. Reeve and Co., London.

17. Prain D (1903) Bengal plants. Vol. 1 \& 2. BSI, Calcutta, India.

18. Haines HH (1921-1925) The botany of Bihar and Orissa. Vol. 1-6, BSI, Calcutta, India.

19. Bennet SSR (1979) Flora of Howrah district. International Book Distributors, Dehradun, India.

20. Sanyal MN (1994) Flora of Bankura district. Bishen Singh and Mahendra Pal Singh, Dehra Dun, India.

21. Mitra JN (1958) Flowering plants of eastern India,Vol. I, Mono- 
cotyledons. The World Press Private Ltd., Calcutta, India.

22. Datta SC, Majumdar NC (1966) Flora of Calcutta and vicinity. Bulletin of Botanical Society of Bengal 20: 16-120.

23. IUCN (2019) The IUCN Red List of Threatened Species. Version 2019-1 <www.iucnredlist.org>. Downloaded on 23 June, 2019.

24. Chase MW, Christenhusz MJM, Fay MF et al. (2016) An update of the Angiosperm Phylogeny Group classification for the orders and families of flowering plants: APG IV. Botanical Journal of Linnean Society 181:1-20.

25. Cain SA (1950) Life-form and phytoclimates. Botanical Review 16(1): 1-32.

26. Muller D, Ellenberg H (1974) Aims and methods of vegetation ecology. John Wiley and sons, New York, USA.

27. Chigani HK, Javadi SA, Zahedi-Amiri G, Khajeddin SJ, Jafari M (2017) Vegetation composition differentiation and speciesenvironment relationships in the northern part of Isfahan Province. Land Degradation and Development 9: 161-175.

28. Wing SL (2000) Evolution and expansion of flowering plants. Journal of Palaeontol Society 6: 209-232.

29. Magallon S, Castillo A (2009) Angiosperm diversification through time. American Journal of Botany 96(1): 349-365.

30. Wang H, Moore MJ, Soltis PS et al. (2009) Rosid radiation and the rapid rise of angiosperm-dominated forests. Proceedings of National Acaddemy of Sciences 106(10): 3853-3858.

31. Batalha MA, Martins FR (2004) Floristic, frequency, and vegetation life-form spectra of a cerrado site. Brazilian Journal of Biology 64(2): 201-209.

32. Sen UK, Bhakat RK (2018) Ethnobotanical study on sand-dune based medicinal plants and traditional therapies in coastal Purba Medinipur District, West Bengal, India. Europian Journal of Medicinal Plants 26(2): 1-19.

33. Davidson AM, Jennions M, Nicotra AB (2011) Do invasive species show higher phenotypic plasticity than native species and, if so, is it adaptive? A meta-analysis. Ecological Letters 14(4): 419-431.

34. Blondel J (2006) The ‘design’ of Mediterranean landscapes: a millennial story of humans and ecological systems during the historic period. Human Ecology 34(5): 713-729.

35. Gurevitch J, Padilla DK (2004) Are invasive species a major cause of extinctions?. Trends in Ecology and Evolution 19 (9): 470-474.

36. Nielsen KE, Hansen B, Ladekarl UL, Nornberg P (2000) Effects of N-deposition on ion trapping by B-horizons of Danish heathlands. Plant Soil 223(1-2): 267-278.

37. Stesevic D, Lukovic M, Cakovic D et al. (2017) Distribution of alien species along sand dune plant communities zonation. Periodicum Biologorum 119(4): 239-249.

38. Van Der Maarel E (2003) Some remarks on the functions of European coastal ecosystems. Phytocoenologia 33(2-3): 187-202.

39. Ayyad MA, El-Ghareeh REM (1982) Salt marsh vegetation of the western Mediterranean desert of Egypt. Vegetatio 49(1): 319

40. Kahveci H, Acar C (2018) Distribution and floristic composition of coastal vegetation in Northeastern Turkey. American Journal of Engineering Research 7(12): 205-220.

41. Al Shaye NA, Masrahi YS, Thomas J (2019) Ecological significance of floristic composition and life forms of Riyadh region, Central Saudi Arabia. Saudi Journal of Biological Science https://doi.org/10.1016/j.sjbs.2019.04.009.

42. Youssef A, Al-Fredan MA (2008) Community composition of major vegetations in the coastal area of Al-Uqair, Saudi Arabia in response to ecological variations. Pak Journal of Biological Sciences 8(4): 713-721.

43. Mascarenhas A (2000) Human interference along the coast of Goa. In: Sharma VK, ed. Environmental problems of coastal areas in India. Bookwell Publishers, New Delhi, India. pp 145171.

44. Brown AC, McLachlan A (2002) Sandy shore ecosystems and the threats facing them: some predictions for the year 2025. Environmental Conservation 29(1): 62-77.

45. Pinna MS, Bacchetta G, Cogoni D, Fenu G (2019) Is vegetation an indicator for evaluating the impact of tourism on the conservation status of Mediterranean coastal dunes?. Science of the Total Environment 674: 255-263.

46. Campos JA, Herrera M, Biurrun I, Loidi J (2004) The role of alien plants in the natural coastal vegetation in central-northern Spain. Biodiversity Conservation 13(12): 2275-2293.

47. Meher-Homji VM (1964) Life forms and biological spectra as epharmonic criteria of aridity and humidity in tropics. Journal of Indian Botanical Society 43: 424-430.

48. Zahran MA (2010) Climate-vegetation: Afro-Asian Mediterranean and Red Sea coastal lands. Vol. 4. Springer Science \& Business Media.

49. Lundberg A (1987) Sand dune vegetation on Karmoy, SW Norway. Nordic Journal of Botany 7(4): 453-477.

50. Visser EJW, Colmer TD, Blom CWPM, Voesenek LACJ (2008) Changes in growth, porosity and radical oxygen loss from adventitious roots of selected mono and dicotyledonous wetland species with contrasting types of aerenchyma. Plant Cell and Environment 23(11): 1237-1245.

51. Lavrentiades G (1971) On the vegetation of sand dunes of Greek coasts. Colloques Phyto-sociologiques 1: 91-98.

52. Mack RN (2003) Phylogenetic constraint, absent life forms, and preadapted alien plants: a prescription for biological invasions. International Journal of Plant Science 164(S3): S185-S196.

53. Sen UK, Bhakat RK (2019a) Assessment of floristic composition, biological spectrum, leaf size spectra and traditional conservation management of a sacred grove in West Midnapore District, West Bengal, India. Indian Forester 145(2): 156-171.

54. Sen UK, Bhakat RK (2019b) Floristic and phytoclimatic study of a sacred grove vegetation of West Midnapore District, West 
Bengal, India. Journal of Tropical Life Science 9(2): 119-138.

55. Zohary M (1962) Plant life of Palestine, Israel and Jordan. Ronald Publisher, New York, USA.

56. Amjad MS (2012) Life form and leaf size spectra of vegetation in Kotli Hills, Azad Jammu and Kashmir (Pakistan). Greener Journal of Agricultural Science 2(7): 345-350.

57. Tareen RB, Qadir SA (1993) Life form and leaf size spectra of the plant communities of diverse areas ranging from Harnai, Sinjawi to Duki regions of Pakistan. Pakistan Journal of Botany 25: 83-92.

58. Krober W, Bohnke M, Welk E et al. (2012) Leaf trait-environment relationships in a subtropical broadleaved forest in SouthEast China. PloS one 7(4): e35742.

59. Hamann O (1979) On climatic conditions, vegetation types, and leaf size in the Galapagos Islands. Biotropica 11(2): 101-122.

60. Box EO (2019) Form and character diversity of potential world vegetation. Flora 254: 203-221. doi: 10.1016/j.flora.2019.03.001.

61. Black KP, Baba M, Kurian NP et al. (2017) Climate change adaptation guidelines for coastal protection and management in
India. Climate Resilient Coastal project, Global Environment Facility and Asian Development Bank.

62. Malhado ACM, Whittaker RJ, Malhi Y et al. (2009) Spatial distribution and functional significance of leaf lamina shape in Amazonian forest trees. Biogeosciences 6: 1577-1590.

63. Manzoni S, Vico G, Porporato A, Katul G (2013) Biological constraints on water transport in the soil-plant-atmosphere system. Advances in Water Resources 51: 292-304.

64. Westoby M, Falster DS, Moles AT et al. (2002) Plant ecological strategies: some leading dimensions of variation between species. Annual Review of Ecology 33(1): 125-159.

65. Cleland EE, Chuine I, Menzel A et al. (2007) Shifting plant phenology in response to global change. Trends in Ecology and Evolution 22(7): 357-365.

66. Brummitt N, Bachman SP, Moat J (2008) Applications of the IUCN Red List: towards a global barometer for plant diversity. Endanger Species Research 6(2): 127-135.

67. Didham RK, Tylianakis JM, Hutchison MA et al. (2005) Are invasive species the drivers of ecological change?. Trends in Ecology and Evolution 20 (9): 470-474. 


\section{Supplementary 1}

Table 4. Database of dominant coastal salt marsh and sand dune species diversity

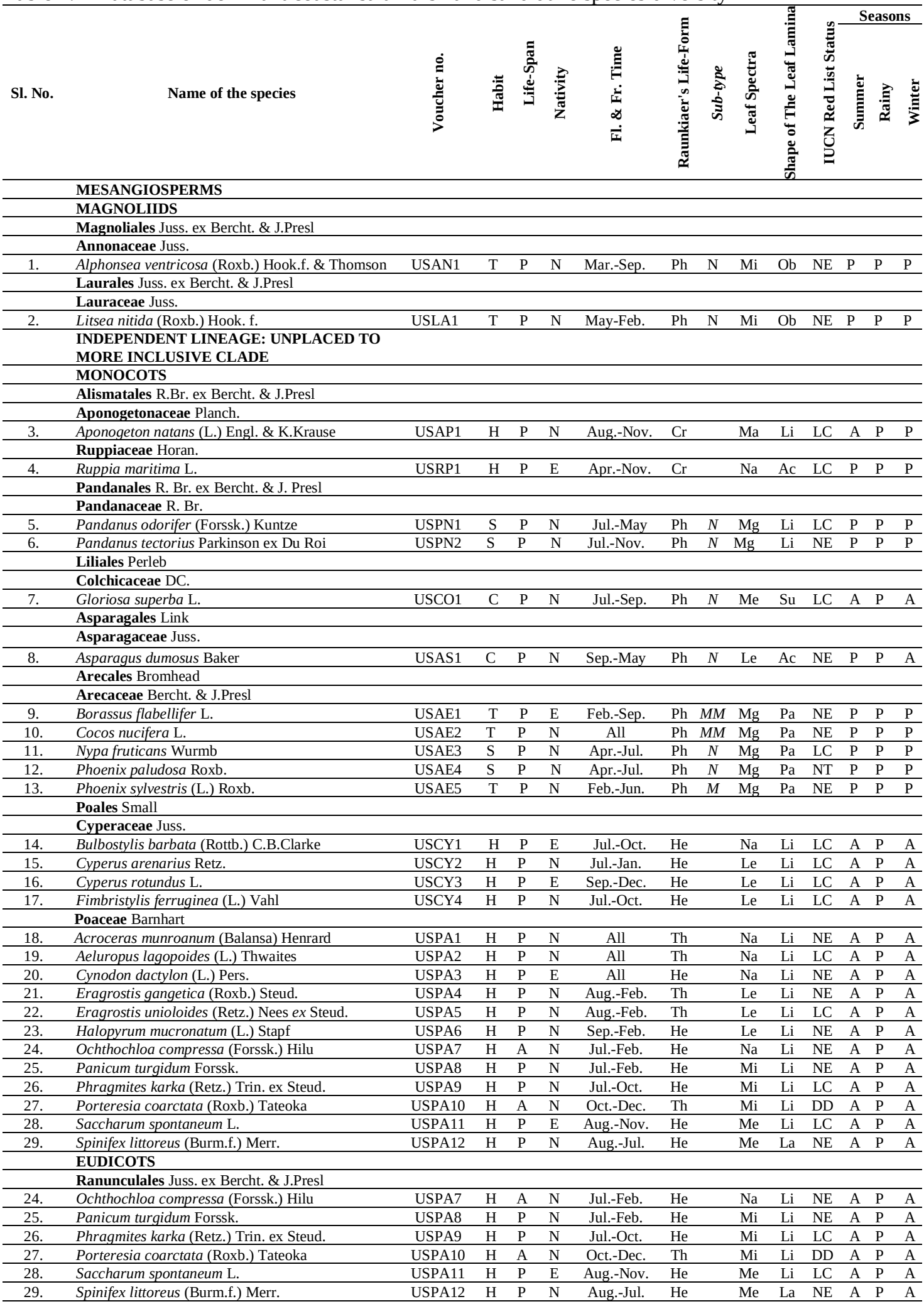

Continue... 
Table 4. Database of dominant coastal salt marsh and sand dune species diversity

\begin{tabular}{|c|c|c|c|c|c|c|c|c|c|c|c|c|c|c|}
\hline \multirow[t]{4}{*}{ Sl. No. } & Name of the species & 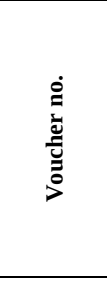 & $\begin{array}{l}\text { : } \\
\text { 苛 }\end{array}$ & 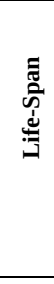 & 胥 & 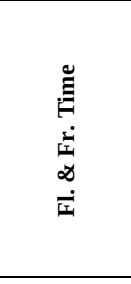 & 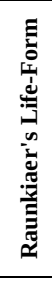 & 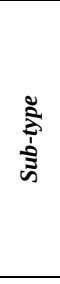 & 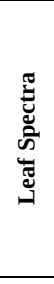 & 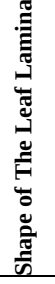 & 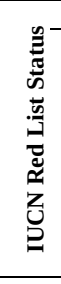 & 离 & 胥 & \\
\hline & \multicolumn{14}{|l|}{ EUDICOTS } \\
\hline & \multirow{2}{*}{\multicolumn{14}{|c|}{$\begin{array}{l}\text { Ranunculales Juss. ex Bercht. \& J.Presl } \\
\text { Papaveraceae Juss. }\end{array}$}} \\
\hline & & & & & & & & & & & & & & \\
\hline \multirow[t]{4}{*}{30.} & Argemone mexicana L. & USPP1 & $\mathrm{H}$ & A & E & Dec.-Apr. & Th & & $\mathrm{Mg}$ & Oo & $\mathrm{NE}$ & $\mathrm{P}$ & $\mathrm{A}$ & $\mathrm{P}$ \\
\hline & SUPERROSIDS & & & & & & & & & & & & & \\
\hline & Saxifragales Bercht. \& J.Presl & & & & & & & & & & & & & \\
\hline & Haloragaceae R.Br. & & & & & & & & & & & & & \\
\hline \multirow[t]{4}{*}{31.} & Myriophyllum indicum Willd. & USHA1 & $\mathrm{H}$ & $\mathrm{P}$ & $\mathrm{N}$ & May-Sep. & Th & & $\mathrm{Na}$ & $\mathrm{Li}$ & LC & A & $\mathrm{P}$ & \\
\hline & ROSIDS & & & & & & & & & & & & & \\
\hline & Vitales Juss. Ex Berht. \& Presl. & & & & & & & & & & & & & \\
\hline & Vitaceae Juss. & & & & & & & & & & & & & \\
\hline \multirow[t]{3}{*}{32.} & Cissus quinquangularis Chiov. & USVT1 & C & $P$ & $\mathrm{~N}$ & Jul.-Jan. & $\mathrm{Ph}$ & $N$ & No & Co & NE & $\mathrm{P}$ & $\mathrm{P}$ & \\
\hline & Zygophyllales Link & & & & & & & & & & & & & \\
\hline & \begin{tabular}{|l} 
Zygophyllaceae R.Br. \\
Balanites roxburahii Planch.
\end{tabular} & USZG1 & $T_{1}$ & $P$ & $\mathrm{~N}$ & D. -Jul. & $\mathrm{Ph}$ & $N$ & No & Ov & $\mathrm{NF}$ & $P$ & & \\
\hline \multirow[t]{3}{*}{34.} & Tribulus terrestris L. & USZG2 & $\mathrm{C}$ & A & $\mathrm{N}$ & Feb.-Sep. & Th & & $\mathrm{Mi}$ & Ov & LC & $\mathrm{P}$ & $\mathrm{P}$ & \\
\hline & Fabales Bromhead & & & & & & & & & & & & & \\
\hline & Fabaceae Lindl. & & & & & & & & & & & & & \\
\hline 35. & Acacia jacquemontii Benth. & USFA1 & $\mathrm{S}$ & $P$ & $\mathrm{~N}$ & May-Sep. & $\mathrm{Ph}$ & $N$ & $\mathrm{Na}$ & Ov & $\mathrm{NE}$ & $\mathrm{P}$ & $\mathrm{P}$ & \\
\hline 36. & Acacia senegal (L.) Willd. & USFA2 & $\mathrm{T}$ & $\mathrm{P}$ & $\mathrm{N}$ & May-Nov. & $\mathrm{Ph}$ & $N$ & $\mathrm{Na}$ & Ov & $\mathrm{NE}$ & $\mathrm{P}$ & $\mathrm{P}$ & \\
\hline 37. & Alysicarpus hamosus Edgew. & USFA3 & $\mathrm{H}$ & A & $\mathrm{N}$ & Nov.-Jan. & Th & & $\mathrm{Na}$ & Co & $\mathrm{NE}$ & $\mathrm{A}$ & $\mathrm{P}$ & $\mathrm{P}$ \\
\hline 38. & Caesalpinia bonduc (L.) Roxb. & USFA4 & $\mathrm{C}$ & $\mathrm{P}$ & $\mathrm{N}$ & Aug.-Apr. & $\mathrm{Ph}$ & $N$ & $\mathrm{Me}$ & Co & LC & $\mathrm{P}$ & $\mathrm{P}$ & \\
\hline 39. & Canavalia rosea (Sw.) DC. & USFA5 & $\mathrm{C}$ & & $E$ & All & $\mathrm{Ph}$ & $N$ & No & $\mathrm{Ov}$ & $\mathrm{NE}$ & $\mathrm{P}$ & $\mathrm{P}$ & $\mathrm{P}$ \\
\hline 40. & Crotalaria burhia Benth. & USFA6 & $\mathrm{S}$ & A & $\mathrm{N}$ & All & $\mathrm{Ch}$ & & $\mathrm{Mi}$ & $\mathrm{Ob}$ & NE & $\mathrm{P}$ & $P$ & \\
\hline 41. & Crotalaria medicaginea Lam. & USFA7 & $\mathrm{S}$ & A & $\mathrm{N}$ & Jan.-Mar. & $\mathrm{Ch}$ & & $\mathrm{Mi}$ & $\mathrm{Ob}$ & $\mathrm{NE}$ & $\mathrm{A}$ & $\mathrm{P}$ & \\
\hline 42. & Crotalaria retusa L. & USFA8 & $\mathrm{S}$ & & $\mathrm{N}$ & Jul.-Jan. & $\mathrm{Ch}$ & & $\mathrm{Mi}$ & $\mathrm{Ob}$ & $\mathrm{NE}$ & A & $\mathrm{P}$ & $\mathrm{P}$ \\
\hline 43. & Crotalaria verrucosa $\mathrm{L}$. & USFA9 & $\mathrm{S}$ & & $\mathrm{N}$ & Jul.-Jan. & Ch & & $\mathrm{Mi}$ & $\mathrm{Ob}$ & $\mathrm{NE}$ & A & $\mathrm{P}$ & \\
\hline 44. & Cynometra iripa Kostel. & USFA10 & $\mathrm{s}$ & $\mathrm{A}$ & $\mathrm{N}$ & Mar.-Aug. & $\mathrm{Ph}$ & $N$ & $\mathrm{Mi}$ & $\mathrm{Ob}$ & LC & $\mathrm{P}$ & $\mathrm{P}$ & $\mathrm{P}$ \\
\hline 45. & Dalbergia spinosa Roxb. & USFA11 & $\mathrm{C}$ & A & $N$ & Mar.-Jun. & $\mathrm{Ph}$ & $N$ & $\mathrm{Na}$ & Oo & NE & $\mathrm{P}$ & $\mathrm{P}$ & \\
\hline 46. & Delonix elata (L.) Gamble & USFA12 & $\mathrm{T}$ & $\mathrm{P}$ & $\mathrm{N}$ & Mar.-Jul. & $\mathrm{Ph}$ & $N$ & $\mathrm{Na}$ & $\mathrm{Ob}$ & LC & $\mathrm{P}$ & $\mathrm{P}$ & $\mathrm{P}$ \\
\hline 47. & Derris scandens (Roxb.) Benth. & USFA13 & $\mathrm{C}$ & $\mathrm{P}$ & $\mathrm{N}$ & $\begin{array}{l}\text { Jul.-Jan. } \\
\end{array}$ & $\mathrm{Ph}$ & $N$ & $\mathrm{Na}$ & $\mathrm{Ob}$ & LC & $\mathrm{P}$ & $\mathrm{P}$ & \\
\hline 48. & Derris trifoliata Lour. & USFA14 & $\mathrm{C}$ & $\mathrm{P}$ & $\mathrm{N}$ & Mar.-Aug. & $\mathrm{Ph}$ & $N$ & $\mathrm{Na}$ & $\mathrm{Ob}$ & $\mathrm{NE}$ & $\mathrm{P}$ & $\mathrm{P}$ & $\mathrm{P}$ \\
\hline 49. & Desmodium dichotomum (Willd.) DC. & USFA15 & $\mathrm{H}$ & $\mathrm{P}$ & $\mathrm{N}$ & Aug.-Jun. & Th & & $\mathrm{Na}$ & Ov & $\mathrm{NE}$ & A & & \\
\hline 50. & Erythrina variegata $\mathrm{L}$. & USFA16 & $\mathrm{T}$ & $\mathrm{P}$ & $\mathrm{N}$ & Mar.-Jul. & $\mathrm{Ph}$ & $N$ & $\mathrm{Me}$ & Co & LC & $\mathrm{P}$ & $\mathrm{P}$ & $\mathrm{P}$ \\
\hline 51. & Intsia bijuga (Colebr.) Kuntze & USFA17 & $\mathrm{T}$ & $\mathrm{P}$ & $\mathrm{N}$ & Jun.-Dec. & $\mathrm{Ph}$ & $M$ & $\mathrm{Me}$ & $\mathrm{Ob}$ & VU & $\mathrm{P}$ & $\mathrm{P}$ & \\
\hline 52. & Mimosa pudica L. & USFA18 & $\mathrm{H}$ & $\mathrm{P}$ & $E$ & Jul.-Nov. & Th & & $\mathrm{Na}$ & $\mathrm{La}$ & LC & A & $\mathrm{P}$ & $\mathrm{P}$ \\
\hline 53. & Mucuna gigantea (Willd.) DC. & USFA19 & $\mathrm{C}$ & A & $\mathrm{N}$ & Dec.-Mar. & $\mathrm{Ph}$ & $N$ & $\mathrm{Me}$ & Co & $\mathrm{NE}$ & A & $\mathrm{P}$ & \\
\hline 54. & Pongamia pinnata (L.) Pierre & USFA20 & $\mathrm{T}$ & $\mathrm{P}$ & $\mathrm{N}$ & Apr.-Feb. & $\mathrm{Ph}$ & $M$ & $\mathrm{Me}$ & Co & LC & $\mathrm{P}$ & $\mathrm{P}$ & $\mathrm{P}$ \\
\hline 55. & Prosopis cineraria (L.) Druce & USFA21 & $\mathrm{T}$ & $\mathrm{P}$ & $\mathrm{E}$ & Apr.-Feb. & $\mathrm{Ph}$ & $M$ & $\mathrm{Na}$ & Ov & $\mathrm{NE}$ & $\mathrm{P}$ & & \\
\hline 56. & Prosopis juliflora (Sw.) DC. & USFA22 & $\mathrm{T}$ & $\mathrm{P}$ & E & Apr.-Feb. & $\mathrm{Ph}$ & $M$ & $\mathrm{Na}$ & Ov & $\mathrm{NE}$ & $\mathrm{P}$ & $\mathrm{P}$ & $\mathrm{P}$ \\
\hline 57. & Rhynchosia minima (L.) DC. & USFA23 & $\mathrm{C}$ & $\mathrm{P}$ & $\mathrm{N}$ & Sep.-Feb. & $\mathrm{Ph}$ & $N$ & $\mathrm{Me}$ & Co & LC & A & $\mathrm{P}$ & \\
\hline 58. & Rothia indica (L.) Druce & USFA24 & $\mathrm{H}$ & A & $\mathrm{N}$ & Aug.-Feb. & Th & & No & $\mathrm{Ob}$ & $\mathrm{NE}$ & A & $\mathrm{P}$ & $\mathrm{P}$ \\
\hline 59. & Senna auriculata (L.) Roxb. & USFA25 & $\mathrm{S}$ & $\mathrm{P}$ & $E$ & Mar.-Aug. & $\mathrm{Ch}$ & & No & $\mathrm{Ob}$ & $\mathrm{NE}$ & $\mathrm{P}$ & $\mathrm{P}$ & \\
\hline 60. & Senna occidentalis (L.) Link & USFA26 & $\mathrm{S}$ & $\mathrm{P}$ & $E$ & Aug.-Dec. & $\mathrm{Ch}$ & & No & Co & $\mathrm{NE}$ & $\mathrm{A}$ & $\mathrm{P}$ & $\mathrm{P}$ \\
\hline 61. & Tephrosia maxima (L.) Pers. & USFA27 & $\mathrm{H}$ & $P$ & E & Sep.-Nov. & Th & & $\mathrm{Na}$ & $\mathrm{Ob}$ & $\mathrm{NE}$ & $\mathrm{P}$ & $\mathrm{P}$ & $\mathrm{P}$ \\
\hline 62. & Tephrosia purpurea (L.) Pers. & USFA28 & $\mathrm{H}$ & $\mathrm{P}$ & $\mathrm{N}$ & Sep.-Dec. & Th & & $\mathrm{Na}$ & $\mathrm{Ob}$ & LC & $\mathrm{P}$ & $\mathrm{P}$ & $\mathrm{P}$ \\
\hline 63. & Tephrosia villosa (L.) Pers. & USFA29 & $\mathrm{H}$ & $\mathrm{P}$ & $\mathrm{N}$ & Jul.-Oct. & Th & & $\mathrm{Na}$ & $\mathrm{Ob}$ & LC & $\mathrm{P}$ & $\mathrm{P}$ & $\mathrm{P}$ \\
\hline 64. & Vachellia tortilis (Forssk.) Galasso and Banfi & USFA30 & $\mathrm{T}$ & $\mathrm{P}$ & E & May-Aug. & $\mathrm{Ph}$ & $M$ & $\mathrm{Na}$ & Ov & $\mathrm{NE}$ & $\mathrm{P}$ & $\mathrm{P}$ & $\mathrm{P}$ \\
\hline \multirow[t]{3}{*}{65.} & Zornia diphylla (L.) Pers. & USFA31 & $\mathrm{H}$ & A & $\mathrm{N}$ & Aug.-Feb. & Th & & $\mathrm{Na}$ & Ov & $\mathrm{NE}$ & A & $\mathrm{P}$ & $\mathrm{P}$ \\
\hline & Rosales Bercht. \& J.Presl & & & & & & & & & & & & & \\
\hline & & & & & & & & & & & & & & \\
\hline 66. & Ziziphus jujuba Mill. & USRA1 & $\mathrm{T}$ & $\mathrm{P}$ & E & Sep.-Mar. & $\mathrm{Ph}$ & $M$ & $\mathrm{Mi}$ & Co & LC & $\mathrm{P}$ & $\mathrm{P}$ & \\
\hline \multirow[t]{3}{*}{67.} & Ziziphus nummularia (Burm.f.) Wight and Arn. & USRA2 & $\mathrm{S}$ & $\mathrm{P}$ & $E$ & Feb.-Apr. & Ch & & $\mathrm{Mi}$ & Co & $\mathrm{NE}$ & $\mathrm{P}$ & $\mathrm{P}$ & $\mathrm{P}$ \\
\hline & Fagales Engl. & & & & & & & & & & & & & \\
\hline & Casuarinaceae R.Br. & & & & & & & & & & & & & \\
\hline \multirow[t]{3}{*}{68.} & Casuarina equisetifolia $\mathrm{L}$. & USCS1 & $\mathrm{T}$ & $\mathrm{P}$ & $\mathrm{N}$ & Apr.-Oct. & $\mathrm{Ph}$ & $M M$ & Le & Ac & LC & $\mathrm{P}$ & $\mathrm{P}$ & $\mathrm{P}$ \\
\hline & Celastrales Link & & & & & & & & & & & & & \\
\hline & Celastraceae R.Br. & & & & & & & & & & & & & \\
\hline \multirow[t]{3}{*}{69.} & Salacia chinensis L. & USCL1 & $\mathrm{C}$ & $\mathrm{P}$ & $\mathrm{N}$ & Feb.-Apr. & $\mathrm{Ph}$ & $N$ & $\mathrm{Me}$ & $\mathrm{Ob}$ & $\mathrm{NE}$ & $\mathrm{P}$ & $\mathrm{P}$ & $\mathrm{P}$ \\
\hline & Malpighiales Juss. ex Bercht. \& J.Presl & & & & & & & & & & & & & \\
\hline & & & & & & & & & & & & & & \\
\hline 70. & Bruguiera gymnorhiza (L.) Lam. & USRH1 & $\mathrm{T}$ & $\mathrm{P}$ & $\mathrm{N}$ & Jun.-Oct. & $\mathrm{Ph}$ & $N$ & $\mathrm{Me}$ & $\mathrm{La}$ & LC & $\mathrm{P}$ & $\mathrm{P}$ & \\
\hline
\end{tabular}

Continue... 
Table 4. Database of dominant coastal salt marsh and sand dune species diversity

\begin{tabular}{|c|c|c|c|c|c|c|c|c|c|c|c|c|c|c|}
\hline Sl. No. & Name of the species & 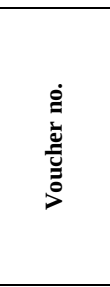 & 言 & 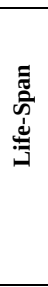 & 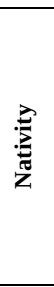 & 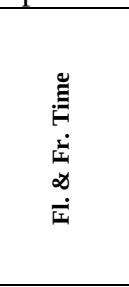 & 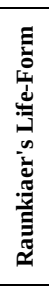 & 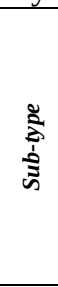 & 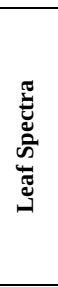 & 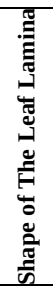 & 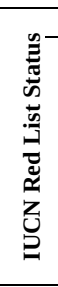 & 离 & 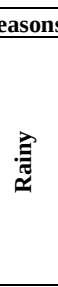 & 离 \\
\hline 71. & Bruguiera sexangula (Lour.) Poir. & USRH2 & $\mathrm{T}$ & & $\mathrm{N}$ & Jul.-Jan. & $\mathrm{Ph}$ & $N$ & $\mathrm{Me}$ & $\mathrm{La}$ & $\mathrm{LC}$ & $\mathrm{P}$ & $\mathrm{P}$ & $\mathrm{P}$ \\
\hline 72. & Ceriops decandra (Griff.) W.Theob. & USRH3 & $\mathrm{T}$ & & $\mathrm{N}$ & Apr.-Oct. & $\mathrm{Ph}$ & $M M$ & $\mathrm{Me}$ & $\mathrm{Ob}$ & NT & $\mathrm{P}$ & $\mathrm{P}$ & $\mathrm{P}$ \\
\hline 73. & Ceriops tagal (Perr.) C.B.Rob. & USRH4 & $\mathrm{T}$ & & $\mathrm{N}$ & Aug.-Mar. & $\mathrm{Ph}$ & $N$ & $\mathrm{Me}$ & $\mathrm{Ob}$ & LC & $\mathrm{P}$ & $\mathrm{P}$ & $\mathrm{P}$ \\
\hline 74. & Kandelia candel (L.) Druce & USRH5 & $\mathrm{T}$ & $\mathrm{P}$ & $\mathrm{N}$ & Jan.-Aug. & $\mathrm{Ph}$ & $N$ & $\mathrm{Me}$ & $\mathrm{La}$ & $\mathrm{LC}$ & $\mathrm{P}$ & $\mathrm{P}$ & $\mathrm{P}$ \\
\hline 75. & Rhizophora apiculata Blume & USRH6 & $\mathrm{T}$ & $\mathrm{P}$ & $\mathrm{N}$ & Apr.-Jul. & $\mathrm{Ph}$ & $M$ & $\mathrm{Me}$ & $\mathrm{La}$ & LC & $\mathrm{P}$ & $\mathrm{P}$ & $\mathrm{P}$ \\
\hline \multirow[t]{2}{*}{76.} & Rhizophora mucronata Lam. & USRH7 & $\mathrm{T}$ & $\mathrm{P}$ & $\mathrm{N}$ & Apr.-Jul. & $\mathrm{Ph}$ & $M$ & $\mathrm{Me}$ & $\mathrm{La}$ & LC & $\mathrm{P}$ & $\mathrm{P}$ & $\mathrm{P}$ \\
\hline & Clusiaceae Lindl & & & & & & & & & & & & & \\
\hline \multirow[t]{2}{*}{77.} & Calophyllum inophyllum L. & USCU1 & $\mathrm{T}$ & $\mathrm{P}$ & $\mathrm{N}$ & Jan.-Apr. & $\mathrm{Ph}$ & $M M$ & Ма & $\mathrm{Ob}$ & $\mathrm{LC}$ & $\mathrm{P}$ & $\mathrm{P}$ & $\mathrm{P}$ \\
\hline & Euphorbiaceae Juss. & & & & & & & & & & & & & \\
\hline 78. & Croton bonplandianus Baill. & USEU1 & $\mathrm{H}$ & & E & All & Th & & No & Co & $\mathrm{NE}$ & $\mathrm{P}$ & $\mathrm{P}$ & $\mathrm{P}$ \\
\hline 79. & Euphorbia tithymaloides L. & USEU2 & $\mathrm{H}$ & & $\mathrm{N}$ & Mar.-Apr. & Th & & No & Co & LC & $\mathrm{P}$ & $\mathrm{P}$ & $\mathrm{P}$ \\
\hline 80. & Excoecaria agallocha $\mathrm{L}$. & USEU3 & $\mathrm{T}$ & $\mathrm{P}$ & $\mathrm{N}$ & Nov.-Feb. & $\mathrm{Ph}$ & $N$ & $\mathrm{Me}$ & $\mathrm{La}$ & LC & $\mathrm{P}$ & $\mathrm{P}$ & $\mathrm{P}$ \\
\hline 81. & Jatropha gossypiifolia L. & USEU4 & $\mathrm{S}$ & $\mathrm{P}$ & E & Apr.-Aug. & $\mathrm{Ch}$ & & $\mathrm{Me}$ & Co & $\mathrm{NE}$ & $\mathrm{P}$ & $\mathrm{P}$ & $\mathrm{P}$ \\
\hline \multirow[t]{3}{*}{82.} & Ricinus communis L. & USEU5 & $\mathrm{S}$ & $\mathrm{P}$ & E & Jan.-Apr. & $\mathrm{Ph}$ & $N$ & $\mathrm{Mg}$ & $\mathrm{La}$ & $\mathrm{NE}$ & $\mathrm{P}$ & $\mathrm{P}$ & $\mathrm{P}$ \\
\hline & Myrtales Juss. ex Bercht. \& J.Presl & & & & & & & & & & & & & \\
\hline & Combretaceae R.Br. & & & & & & & & & & & & & \\
\hline \multirow[t]{2}{*}{83.} & Terminalia catappa L. & USCB1 & $\mathrm{T}$ & $\mathrm{P}$ & $\mathrm{N}$ & Apr.-Feb. & $\mathrm{Ph}$ & $M M$ & $\mathrm{Ma}$ & Oo & $\mathrm{NE}$ & $\mathrm{P}$ & $\mathrm{P}$ & $\mathrm{P}$ \\
\hline & Lythraceae J. St.-Hil. & & & & & & & & & & & & & \\
\hline 84. & Sonneratia alba Sm. & USLT1 & $\mathrm{T}$ & $\mathrm{P}$ & $\mathrm{N}$ & May-Aug. & $\mathrm{Ph}$ & $M M$ & No & $\mathrm{La}$ & LC & $\mathrm{P}$ & $\mathrm{P}$ & $\mathrm{P}$ \\
\hline 85. & Sonneratia apetala Buch.-Ham. & USLT2 & $\mathrm{T}$ & $\mathrm{P}$ & $\mathrm{N}$ & Feb.-Nov. & $\mathrm{Ph}$ & $N$ & No & $\mathrm{La}$ & LC & $\mathrm{P}$ & $\mathrm{P}$ & $\mathrm{P}$ \\
\hline \multirow[t]{2}{*}{86.} & Sonneratia griffithii Kurz & USLT3 & $\mathrm{S}$ & $\mathrm{P}$ & $\mathrm{N}$ & Feb.-Jul. & $\mathrm{Ph}$ & $N$ & No & $\mathrm{La}$ & $\mathrm{CR}$ & $\mathrm{P}$ & $\mathrm{P}$ & $\mathrm{P}$ \\
\hline & Myrtaceae Juss. & & & & & & & & & & & & & \\
\hline \multirow[t]{3}{*}{87.} & Eucalyptus globulus Labill. & USMY1 & $\mathrm{T}$ & & $\mathrm{E}$ & Apr.-Mar. & $\mathrm{Ph}$ & $M M$ & $\mathrm{Mi}$ & $\mathrm{La}$ & $\mathrm{NE}$ & $\mathrm{P}$ & $\mathrm{P}$ & $\mathrm{P}$ \\
\hline & Sapindales Juss. ex Bercht. \& J.Presl & & & & & & & & & & & & & \\
\hline & Anacardiaceae R.Br. & & & & & & & & & & & & & \\
\hline 88. & Anacardium occidentale L. & USAA1 & $\mathrm{T}$ & & E & Mar.-Jun. & $\mathrm{Ph}$ & $N$ & $\mathrm{Me}$ & Oo & NE & $\mathrm{P}$ & $\mathrm{P}$ & $\mathrm{P}$ \\
\hline \multirow[t]{2}{*}{89.} & Holigarna caustica (Dennst.) Oken & USAA2 & $\mathrm{T}$ & & $\mathrm{N}$ & Mar.-Oct. & $\mathrm{Ph}$ & $M$ & $\mathrm{Me}$ & Oo & $\mathrm{NE}$ & $\mathrm{P}$ & $\mathrm{P}$ & $\mathrm{P}$ \\
\hline & Rutaceae Juss. & & & & & & & & & & & & & \\
\hline 90. & Glycosmis pentaphylla (Retz.) DC. & USRT1 & $\mathrm{S}$ & $\mathrm{P}$ & $\mathrm{N}$ & Sep.-Apr. & $\mathrm{Ch}$ & & $\mathrm{Na}$ & $\mathrm{La}$ & $\mathrm{NE}$ & $\mathrm{P}$ & $\mathrm{P}$ & $\mathrm{P}$ \\
\hline 91. & Merope angulata Swingle & USRT2 & $\mathrm{S}$ & $\mathrm{P}$ & $\mathrm{N}$ & Apr.- Jul. & $\mathrm{Ch}$ & & $\mathrm{Mi}$ & $\mathrm{La}$ & $\mathrm{NE}$ & $\mathrm{P}$ & $\mathrm{P}$ & $\mathrm{P}$ \\
\hline \multirow[t]{2}{*}{92.} & Toddalia asiatica (L.) Lam. & USRT3 & $\mathrm{C}$ & $\mathrm{P}$ & $\mathrm{N}$ & Sep.-Mar. & $\mathrm{Ph}$ & $N$ & Mi & $\mathrm{La}$ & $\mathrm{NE}$ & $\mathrm{P}$ & $\mathrm{P}$ & $\mathrm{P}$ \\
\hline & Meliaceae Juss. & & & & & & & & & & & & & \\
\hline 93. & Azadirachta indica A. Juss. & USME1 & $\mathrm{T}$ & $\mathrm{P}$ & $\mathrm{N}$ & Mar.-Jul. & $\mathrm{Ph}$ & $M$ & No & $\mathrm{La}$ & LC & $\mathrm{P}$ & $\mathrm{P}$ & $\mathrm{P}$ \\
\hline \multirow[t]{3}{*}{94.} & Xylocarpus granatum J.Koenig & USME2 & $\mathrm{T}$ & $\mathrm{P}$ & $\mathrm{N}$ & Apr.-Jul. & $\mathrm{Ph}$ & $M$ & $\mathrm{Me}$ & Oo & LC & $\mathrm{P}$ & $\mathrm{P}$ & $\mathrm{P}$ \\
\hline & Malvales Juss. ex Bercht. \& J.Presl & & & & & & & & & & & & & \\
\hline & Malvaceae Juss. & & & & & & & & & & & & & \\
\hline 95. & Abelmoschus moschatus Medik. & USML1 & $\mathrm{H}$ & $\mathrm{A}$ & $\mathrm{E}$ & Aug.-Dec. & Th & & $\mathrm{Me}$ & $\mathrm{Sg}$ & $\mathrm{NE}$ & $\mathrm{A}$ & $\mathrm{P}$ & $\mathrm{P}$ \\
\hline 96. & Brownlowia tersa (L.) Kosterm. & USML2 & $\mathrm{S}$ & $\mathrm{P}$ & $\mathrm{N}$ & Jul.-Jan. & $\mathrm{Ch}$ & & No & $\mathrm{La}$ & NT & $\mathrm{P}$ & $\mathrm{P}$ & $\mathrm{P}$ \\
\hline 97. & Heritiera fomes Buch.-Ham. & USML3 & $\mathrm{T}$ & $\mathrm{P}$ & $\mathrm{N}$ & Apr.-Jul. & $\mathrm{Ph}$ & $M$ & $\mathrm{Me}$ & Co & EN & $\mathrm{P}$ & $\mathrm{P}$ & $\mathrm{P}$ \\
\hline 98. & Heritiera kanikensis Majumdar \& L.K.Banerjee & USML4 & $\mathrm{T}$ & $\mathrm{P}$ & $\mathrm{N}$ & Jul.-Mar. & $\mathrm{Ph}$ & $N$ & $\mathrm{Me}$ & Co & $\mathrm{NE}$ & $\mathrm{P}$ & $\mathrm{P}$ & $\mathrm{P}$ \\
\hline 99. & Heritiera littoralis Aiton & USML5 & $\mathrm{T}$ & $\mathrm{P}$ & $\mathrm{N}$ & Jul.-Mar. & $\mathrm{Ph}$ & $N$ & $\mathrm{Me}$ & Co & LC & $\mathrm{P}$ & $\mathrm{P}$ & $\mathrm{P}$ \\
\hline 100. & Hibiscus tilliaceus L. & USML6 & $\mathrm{T}$ & $\mathrm{P}$ & $\mathrm{N}$ & All & $\mathrm{Ph}$ & $N$ & Мa & Co & LC & $\mathrm{P}$ & $\mathrm{P}$ & $\mathrm{P}$ \\
\hline 101. & Sida cordifolia L. & USML7 & S & A & $\mathrm{N}$ & Aug.-Dec. & Th & & $\mathrm{Mi}$ & Co & $\mathrm{NE}$ & A & $\mathrm{P}$ & A \\
\hline 102. & Sida ovata Forssk. & USML8 & $\mathrm{S}$ & $\mathrm{A}$ & $\mathrm{E}$ & Jul.-Feb. & Th & & $\mathrm{Mi}$ & Ov & $\mathrm{NE}$ & A & $\mathrm{P}$ & $\mathrm{P}$ \\
\hline 103. & Thespesia populnea (L.) Sol. ex Corrêa & USML9 & $\mathrm{T}$ & $\mathrm{P}$ & $\mathrm{N}$ & Aug.-Jan. & $\mathrm{Ph}$ & $M$ & $\mathrm{Ma}$ & Co & LC & $\mathrm{P}$ & $\mathrm{P}$ & $\mathrm{P}$ \\
\hline \multirow[t]{3}{*}{104.} & Triumfetta rhomboidea Jacq. & USML10 & $\mathrm{S}$ & A & $\mathrm{N}$ & Aug.-Jan. & $\mathrm{Ch}$ & & $\mathrm{Me}$ & Co & $\mathrm{NE}$ & A & $\mathrm{P}$ & A \\
\hline & Brassicales Bromhead & & & & & & & & & & & & & \\
\hline & Salvadoraceae Lindl. & & & & & & & & & & & & & \\
\hline 105. & Salvadora oleoides Decne. & USSL1 & $\mathrm{T}$ & $\mathrm{P}$ & $\mathrm{N}$ & Aug.-Dec. & $\mathrm{Ph}$ & $N$ & $\mathrm{Me}$ & $\mathrm{Ob}$ & $\mathrm{NE}$ & $\mathrm{P}$ & $\mathrm{P}$ & $\mathrm{P}$ \\
\hline \multirow[t]{2}{*}{106.} & Salvadora persica $\mathrm{L}$. & USSL2 & $\mathrm{S}$ & $\mathrm{P}$ & $\mathrm{N}$ & Aug.-Dec. & $\mathrm{Ph}$ & $N$ & $\mathrm{Me}$ & $\mathrm{Ob}$ & $\mathrm{NE}$ & $\mathrm{P}$ & $\mathrm{P}$ & $\mathrm{P}$ \\
\hline & Capparaceae Juss. & & & & & & & & & & & & & \\
\hline 107. & Capparis decidua (Forssk.) Edgew. & USCP1 & $\mathrm{C}$ & $\mathrm{P}$ & $\mathrm{N}$ & Nov.-Mar. & $\mathrm{Ph}$ & $N$ & Mi & Ov & LC & $\mathrm{P}$ & $\mathrm{P}$ & $\mathrm{P}$ \\
\hline & SUPERASTERIDS & & & & & & & & & & & & & \\
\hline & Caryophyllales Juss. ex Bercht. \& J.Presl & & & & & & & & & & & & & \\
\hline & Tamaricaceae Link & & & & & & & & & & & & & \\
\hline 108. & Tamarix aphylla (L.) H.Karst. & USTM1 & $\mathrm{T}$ & $\mathrm{P}$ & $\mathrm{N}$ & May-Dec. & $\mathrm{Ph}$ & $M$ & $\mathrm{Na}$ & $\mathrm{La}$ & $\mathrm{NE}$ & $\mathrm{P}$ & $\mathrm{P}$ & $\mathrm{P}$ \\
\hline 109. & Tamarix indica Willd. & USTM2 & $\mathrm{T}$ & $\mathrm{P}$ & $\mathrm{N}$ & Mar.-Aug. & $\mathrm{Ph}$ & $N$ & $\mathrm{Na}$ & $\mathrm{La}$ & $\mathrm{NE}$ & $\mathrm{P}$ & $\mathrm{P}$ & $\mathrm{P}$ \\
\hline & Polygonaceae Juss. & & & & & & & & & & & & & \\
\hline 110. & Calligonum polygonoides L. & USPL1 & $S$ & $\mathrm{P}$ & $\mathrm{N}$ & Aug.-Jan. & $\mathrm{Ch}$ & & $\mathrm{Na}$ & Ac & $\mathrm{NE}$ & $\mathrm{P}$ & $\mathrm{P}$ & $\mathrm{P}$ \\
\hline 111. & Rumex dentatus L. & USPL2 & $\mathrm{H}$ & $\mathrm{A}$ & $\mathrm{N}$ & Feb.-Apr. & Th & & $\mathrm{Mi}$ & Ov & LC & $\mathrm{A}$ & $\mathrm{P}$ & $\mathrm{A}$ \\
\hline & Amaranthaceae Juss & & & & & & & & & & & & & \\
\hline
\end{tabular}

Continue... 
Table 4. Database of dominant coastal salt marsh and sand dune species diversity

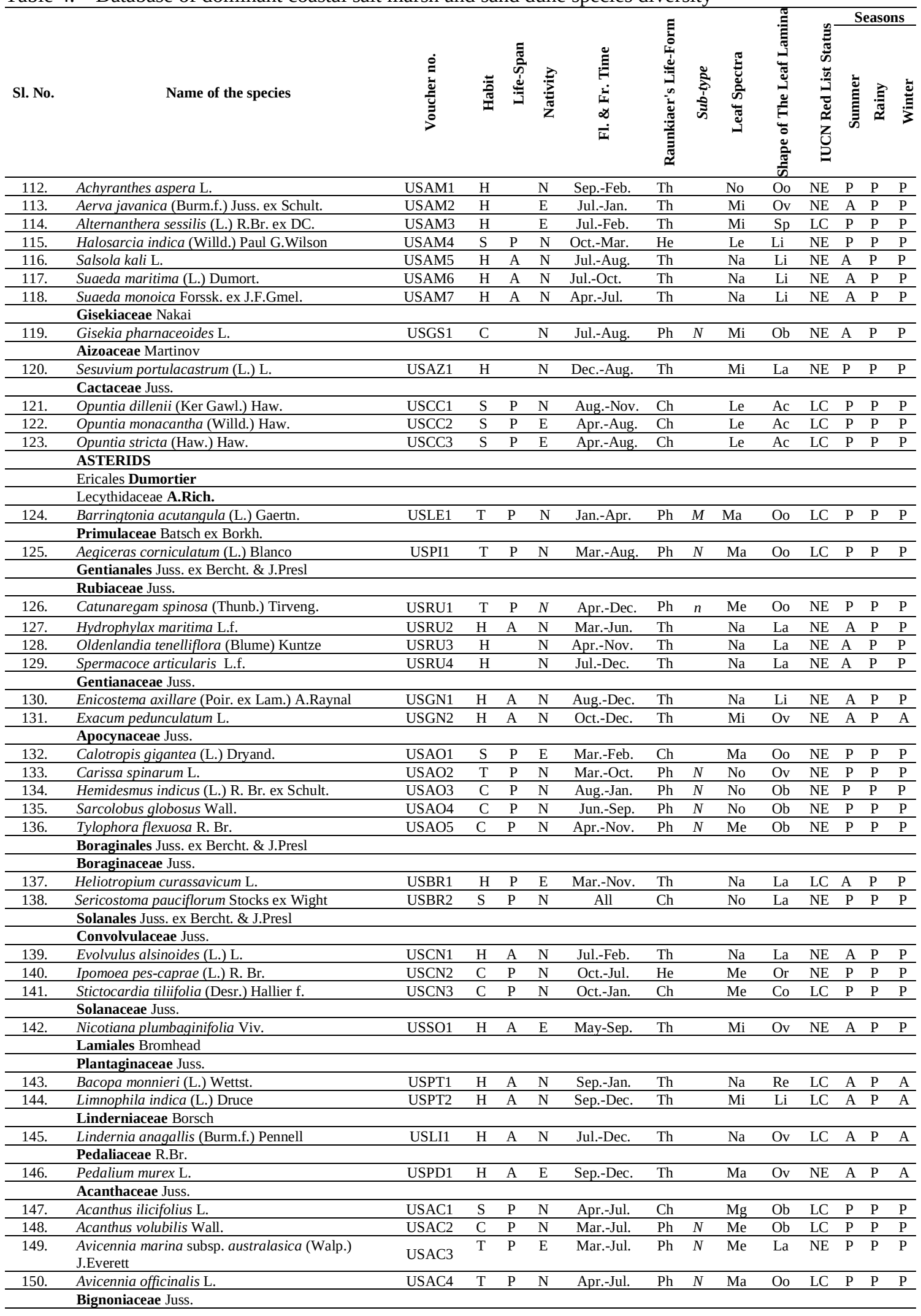

Continue... 
Table 4. Database of dominant coastal salt marsh and sand dune species diversity

\begin{tabular}{|c|c|c|c|c|c|c|c|c|c|c|c|c|c|c|}
\hline Sl. No. & Name of the species & 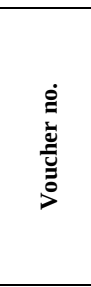 & 章 & 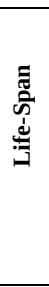 & $\begin{array}{l}\text { 胥 } \\
\text { Z } \\
\text { Z }\end{array}$ & 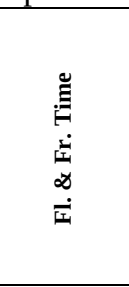 & 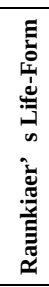 & 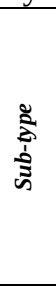 & 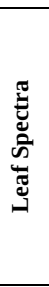 & 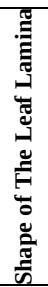 & 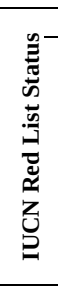 & 离 & 离 & 离 \\
\hline \multirow[t]{2}{*}{151.} & Tecomella undulata (Sm.) Seem. & USBG1 & $\mathrm{T}$ & & $\mathrm{N}$ & Feb.-Apr. & $\mathrm{Ph}$ & $M$ & $\mathrm{Me}$ & $\mathrm{La}$ & NE & $\mathrm{P}$ & $\mathrm{P}$ & $\mathrm{P}$ \\
\hline & Verbenaceae J.St.Hil. & & & & & & & & & & & & & \\
\hline \multirow[t]{2}{*}{152.} & Phyla nodiflora (L.) Greene & USVR1 & $\mathrm{H}$ & & $\mathrm{N}$ & Sep.-Mar. & Th & & $\mathrm{Mi}$ & $\mathrm{Sp}$ & $\mathrm{LC}$ & A & $\mathrm{P}$ & A \\
\hline & Lamiaceae Martinov & & & & & & & & & & & & & \\
\hline 153. & Leucas aspera (Willd.) Link & USLM1 & $\mathrm{H}$ & A & $\mathrm{N}$ & Sep.-Jan. & Th & & No & $\mathrm{La}$ & LC & A & $\mathrm{P}$ & A \\
\hline 154. & Leucas diffusa Benth. & USLM2 & $\mathrm{H}$ & A & $\mathrm{N}$ & Oct.-Dec. & Th & & No & $\mathrm{La}$ & LC & $\mathrm{A}$ & $\mathrm{P}$ & $\mathrm{A}$ \\
\hline 155. & Vitex negundo L. & USLM3 & $\mathrm{T}$ & $\mathrm{P}$ & $\mathrm{N}$ & Mar.-Jan. & $\mathrm{Ph}$ & $N$ & $\mathrm{Mi}$ & $\mathrm{Ob}$ & $\mathrm{NE}$ & $\mathrm{P}$ & $\mathrm{P}$ & $\mathrm{P}$ \\
\hline \multirow[t]{3}{*}{156.} & Volkameria inermis L. & USLM4 & $\mathrm{S}$ & $\mathrm{P}$ & $\mathrm{N}$ & Nov.-Jan. & $\mathrm{Ch}$ & & $\mathrm{Me}$ & $\mathrm{Ob}$ & $\mathrm{NE}$ & $\mathrm{P}$ & $\mathrm{P}$ & $\mathrm{P}$ \\
\hline & Asterales Link & & & & & & & & & & & & & \\
\hline & Asteraceae Bercht. \& J.Presl & & & & & & & & & & & & & \\
\hline 157. & Ageratum conyzoides (L.) L. & USAT1 & $\mathrm{H}$ & & E & Nov.-Mar. & Th & & No & Ov & LC & A & $\mathrm{P}$ & $\mathrm{P}$ \\
\hline 158. & Chromolaena odorata (L.) R.M.King \& H.Rob. & USAT2 & $\mathrm{S}$ & A & $\mathrm{E}$ & Mar.-Sep. & $\mathrm{Ch}$ & & $\mathrm{Mi}$ & Ov & $\mathrm{NE}$ & A & $\mathrm{P}$ & $\mathrm{P}$ \\
\hline 159. & Epaltes australis Less. & USAT3 & $\mathrm{H}$ & A & $\mathrm{N}$ & Aug.-Nov. & Th & & No & Oo & $\mathrm{NE}$ & A & $\mathrm{P}$ & A \\
\hline 160. & Launaea sarmentosa (Willd.) Sch.Bip. ex Kuntze & USAT4 & $\mathrm{H}$ & A & $\mathrm{N}$ & Jun.-Sep. & Th & & $\mathrm{Me}$ & Sp & $\mathrm{NE}$ & $\mathrm{A}$ & $\mathrm{P}$ & A \\
\hline 161. & Parthenium hysterophorus L. & USAT5 & $\mathrm{H}$ & A & $\mathrm{E}$ & All & Th & & $\mathrm{Me}$ & $\mathrm{Li}$ & $\mathrm{NE}$ & $\mathrm{P}$ & $\mathrm{P}$ & $\mathrm{P}$ \\
\hline 162. & Pluchea lanceolata (DC.) C.B.Clarke & USAT6 & $\mathrm{H}$ & $\mathrm{P}$ & E & Aug.-Oct. & Th & & No & $\mathrm{Ob}$ & $\mathrm{NE}$ & $\mathrm{P}$ & $\mathrm{P}$ & $\mathrm{P}$ \\
\hline
\end{tabular}

\section{Abbreviation:}

Habit: C-Climber, H-Herb, S-Shrub, T-Tree

Life-Span: A- Annual, B- Biennial, P-Perennial

Nativity: E-Exotic, N-Native

Flowering and Fruiting time: Jan.-January, Feb.-February, Mar.-March, Apr.-April, Jun.-June, Jul.-July, Aug.August, Sep.-September, Oct.-October, Nov.-November, Dec.-December, All- All season

Raunkiaer's Life-form and Sub-type: Ch- Chamaephytes, Cr- Cryptophytes, He-Hemicryptophytes, MMesophanerophyte, MM- Megaphanerophytes, N- Nanophanerophytes, Ph- Phanerophytes, T-Therophytes

Leaf spectra: Le- Leptophyll, Na-Nanophyll, Mi-Microphyll, No-Notophyll, Me-Mesophyll, Ma-Macrophyll, Mg-Megaphyll

IUCN Status: CR-Critically Endangered, DD-Data Deficient, EN-Endangered, LC- Least Concern, NE -Not Evaluated, NT-Near Threatened, VU-Vulnerable

Leaf Lamina: Ac- Acicular, Co- Cordate, Cu- Cuneate, Ha- Hastate, La- Lanceolate, Li- Linear, Ob- Oblong, Oo- Obovate, Or- Orbicular, Ov- Ovate, Pa- Palm like, Re- Reniform, Sg- Sagitate, Sp- Spathulate, Su- Subulate 